\title{
The late Maastrichtian Belemnella kazimiroviensis group (Cephalopoda, Coleoidea) in the Middle Vistula valley (Poland) and the Maastricht area (the Netherlands, Belgium) - taxonomy and palaeobiological implications
}

\author{
Norbert Keutgen, Zbigniew Remin, and John W.M. Jagt
}

\begin{abstract}
Late late Maastrichtian belemnitellid coleoids of the Belemnella kazimiroviensis group from key sections in the Middle Vistula valley in central Poland and the Maastricht area in the southeast Netherlands and northeast Belgium have been studied and compared with material from Denmark, southern and central Russia, and Central Asia as illustrated in the literature. Two species are recognised: Belemnella (Neobelemnella) kazimiroviensis (Skołozdrówna, 1932) and Belemnella (Neobelemnella) skolozdrownae (Kongiel, 1962). Populations of the kazimiroviensis group in the Nasiłów and Maastricht areas were both dominated by relatively small individuals, which might suggest that a significant number of specimens did not reach the reproductive age or changed habitat during their life cycle. Although part of the studied belemnites came from the Palaeogene deposits, we have found no evidence that they survived the K-Pg boundary, thus are interpreted as reworked.
\end{abstract}

Norbert Keutgen. ZFiPBR, Uniwersytet Techniczno-Przyrodniczy Bydgoszcz, ul. Bernardynska 6/8, 85-029 Bydgoszcz, Poland, and University of Natural Resources and Life Sciences DNW, 1190 Vienna, Austria. norbert.keutgen@boku.ac.at

Zbigniew Remin. Faculty of Geology, University of Warsaw, Al. Żwirki i Wigury 93, 02-089 Warsaw, Poland. zbyh@uw.edu.pl

John W.M. Jagt. Natuurhistorisch Museum Maastricht, de Bosquetplein 6-7, 6211 KJ Maastricht, the Netherlands. john.jagt@maastricht.nl

Keywords: Late Cretaceous; upper Maastrichtian; K-Pg boundary sections; belemnite stratigraphy; Europe Submission: 31 March 2016 Acceptance: 30 June 2017

Keutgen, Norbert, Remin, Zbigniew, and Jagt, John W.M. 2017. The late Maastrichtian Belemnella kazimiroviensis group (Cephalopoda, Coleoidea) in the Middle Vistula valley (Poland) and the Maastricht area (the Netherlands, Belgium) - taxonomy and palaeobiological implications. Palaeontologia Electronica 20.2.38A: 1-29 palaeo-electronica.org/content/2017/1931-belemnites-around-the-ktb

Copyright: August 2017 Palaeontology Association. This is an open access article distributed under the terms of AttributionNonCommercial-ShareAlike 4.0 International (CC BY-NC-SA 4.0), which permits users to copy and redistribute the material in any medium or format, provided it is not used for commercial purposes and the original author and source are credited, with indications if any changes are made.

creativecommons.org/licenses/by-nc-sa/4.0/ 


\section{INTRODUCTION}

Near the end of the Cretaceous Period, during the late Maastrichtian, belemnitellid squid-like cephalopods of the Belemnella kazimiroviensis group appeared in central and western Europe, first in Poland (Middle Vistula River valley) and Denmark, later in the southeast Netherlands and northeast Belgium (Figure 1). This highly successful group probably had its origin in the eastern part of the Russian Platform, close to the beginning of the late Maastrichtian (Christensen, 1997a, 1997b). Belemnella kazimiroviensis was the dominant species at the end of the Maastrichtian Stage, but became extinct, together with other members of the family Belemnitellidae, close to the Cretaceous-Paleogene (K-Pg) boundary.

The area around Kazimierz Dolny (Middle Vistula River valley, central Poland; Figure 2) constitutes the type locality of Bln. kazimiroviensis. Kongiel (1962) listed six belemnite species from the uppermost Maastrichtian of that area; four taxa of the kazimiroviensis group, in addition to rare examples of Belemnitella junior Nowak, 1913 and a single individual of Fusiteuthis polonica Kongiel, 1962. As such, the late Maastrichtian belemnite fauna of the Vistula River valley may be rated as quite rich, representing a centre of diversity in northern Europe.

The four taxa of the kazimiroviensis group described by Kongiel (1962) from the Central Vistula valley are Belemnella pensaensis (Naidin, 1952), Belemnella arkhangelskii Jeletzky, 1951, Belemnella kazimiroviensis and Belemnella skolozdrownae. Naidin (1952) added a further variety to this group: Belemnella pontica (Rousseau, 1842). He interpreted this form as a variety of $B I n$. arkhangelskii and Bln. pensaensis as a second variety of that species. However, the illustration of the holotype of Belemnites ponticus in Rousseau (1842) does not allow any generic and species identification and, at least for the time being, Belemnites ponticus must therefore be considered a nomen dubium.

In view of the fact that the Vistula valley is the 'locus typicus' of Bln. kazimiroviensis, it is essential to describe this species in detail by using material from the type locality and applying modern statistical approaches in order to determine the true number of species of Belemnella represented. In this context it is worthy of note that Naidin (1975) revised his earlier view (Naidin, 1952) and, after having studied populations of the kazimiroviensis group from several localities in southern and cen-

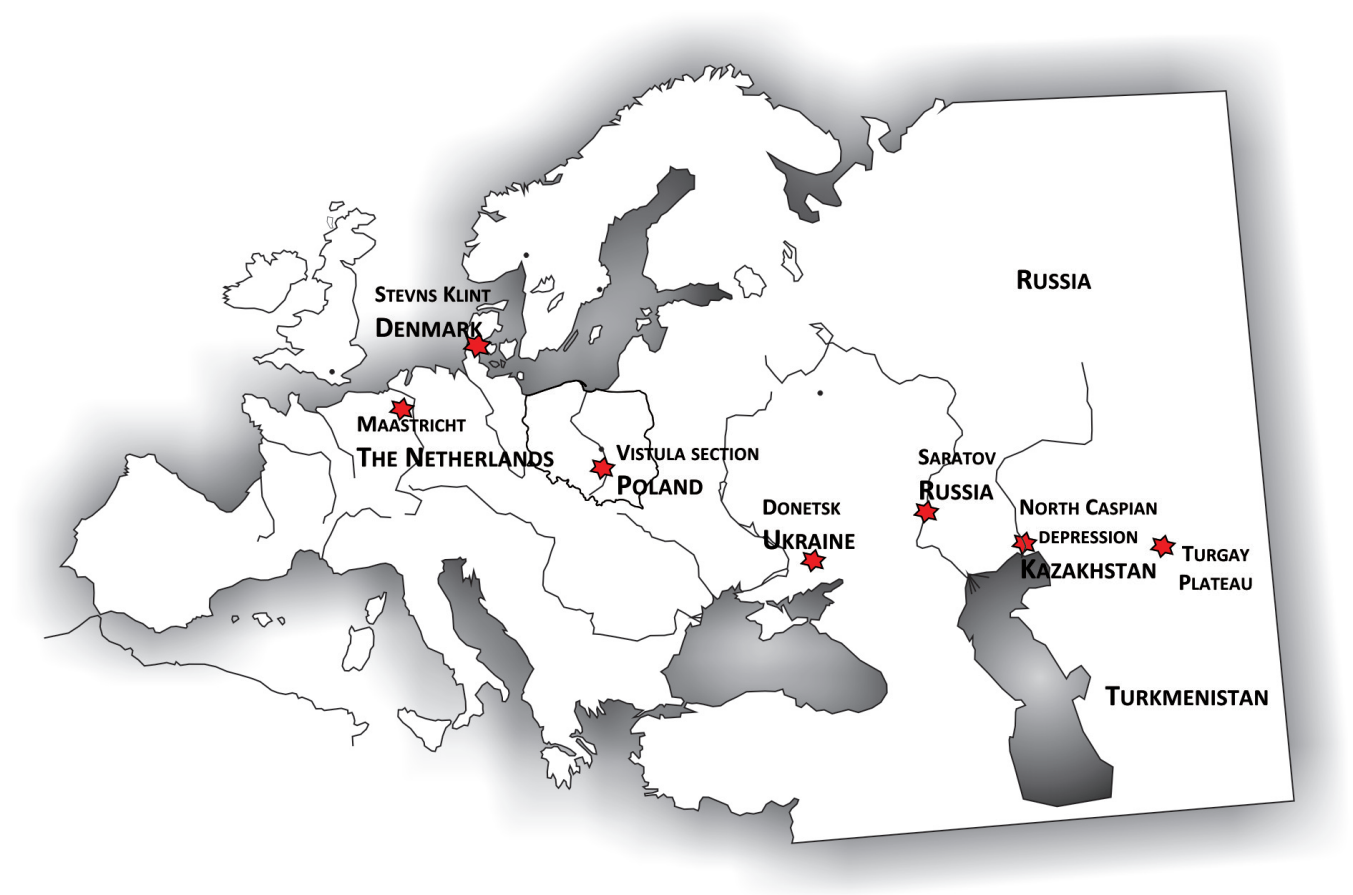

FIGURE 1. Map of Europe and Central Asia, illustrating the general distribution of representatives of the Belemnella kazimiroviensis group as a whole, without differentiation into particular species of the group. The origin of holotype specimens of representatives of this group recorded in the literature are as follows: Belemnella kazimiroviensis - Vistula section; Belemnella skolozdrownae - Stevns Klint; Belemnella pensaensis - Saratov/Penza; Belemnella arkhangelskii - Turgay Plateau. 


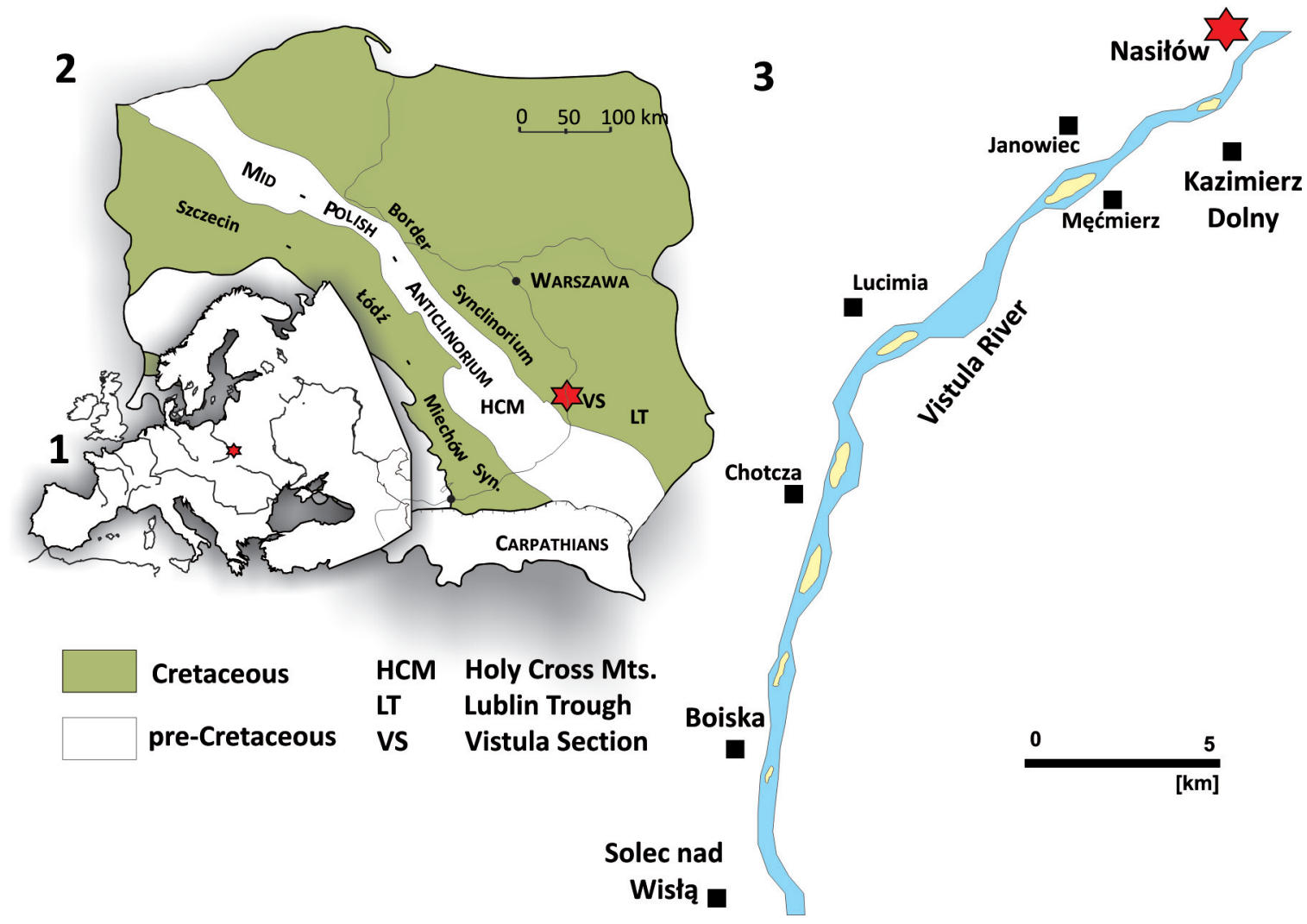

FIGURE 2. 1, location of the Middle Vistula River valley section in the Europe; 2, location in Poland together with the schematic extension of the Cretaceous and pre-Cretaceous deposits in Poland (without the Cenozoic cover); 3, position of Nasiłów along the Vistula River between the villages of Solec nad Wisłą and Kazimierz.

tral Russia and Central Asia, concluded that only a single species was present, i.e., Bln. kazimiroviensis, characterised by a wide range of variation in the shape of the ventral fissure in all populations. Christensen (1996, 1997a, 1997b) adopted Naidin's 1975 view and, in summary, noted (Christensen 1996, 1997a, 1997b) that BIn. kazimiroviensis represented a mostly eastern European and Central Asian taxon, which spread into western Europe during the late Maastrichtian. According to Machalski (1996), it first appeared in Poland and Denmark during the mid- to late late Maastrichtian and reached the Maastricht area (the Netherlands, Belgium) during the latest Maastrichtian.

The kazimiroviensis group most likely evolved in the eastern part of the Russian Platform, presumably deriving from a species related to Belemnella gr. praearkhangelskii Naidin, 1964. The record of Bln. gr. kazimiroviensis in Azerbaijan, Caucasus (Naidin, 1964, 1975) during the entire late Maastrichtian implies migration into the northern peripheries of the Tethyan Realm. The kazimiroviensis group further extended to central
Russia and subsequently to central and western Europe. Representatives of this group persisted for more than two million years and successively extended their range towards the south, north, and west. At the end of the Maastrichtian Stage they even replaced Blt. junior as the dominant belemnitellid in western Europe. It may be expected that the success of the kazimiroviensis group was accompanied by geographic isolation of populations, thus hampering gene interchange. The vicariant populations may have experienced genotypic or phenotypic divergence, for example as a result of different selection pressures or, in the case of small founder populations, of genetic drift. In consequence, it may be assumed that local species could have evolved within this group during the late Maastrichtian, which in turn could have extended their area of distribution.

The aim of the present study was not to revise the kazimiroviensis group across its entire distributional area, but to clarify the systematics of its members in Poland and the Dutch-Belgian border region, on the basis of the concept that Schulz 
(1979) developed for early Maastrichtian species of Belemnella (subgenera Belemnella and Pachybelemnella), which was subsequently improved by one of us (NK). In a separate ongoing study (lead by ZR), these belemnites will be analysed using the method developed by Remin (2008, 2012, 2015) as based on the application of unsupervised Kohonen artificial neural networks for classification purposes.

\section{MATERIAL AND METHODS}

\section{Localities and Provenance of Material}

For the present project, belemnite guards (rostra) were collected in Poland (Nasiłów; Middle Vistula River valley) and in the Dutch-Belgian borderland around Maastricht (Albert Canal near Vroenhoven; Geulhemmerberg subterranean galleries near Geulhem). In addition, material contained in various museum collections was studied, namely the Natuurhistorisch Museum Maastricht (NHMM), Muzeum Ziemi, Polska Akademia Nauk, Warsaw (MZ) and the S.J. Thugutt Geological Museum, Faculty of Geology, University of Warsaw (MWGUW). For the sake of comparison, specimens from Poland and the Dutch-Belgian border area were interpreted within their stratigraphical context, whereas those from Denmark, Russia, Kazakhstan, and Turkmenistan were included in order to test for obvious differences between the western and central European forms of the kazimiroviensis group. Those from central and southern Russia and Central Asia are based on measurements taken from complete and longitudinally split specimens as illustrated in the literature (Jeletzky, 1951; Birkelund, 1957; Naidin, 1975; Alekseev et al., 1999; Naidin and Beniamovski, 2006).

For sections studied in Poland and the Netherlands, lithostratigraphical logs are provided; for details on Maastrichtian strata in these areas reference is made to Machalski (2005a) and Jagt et al. (1996), respectively.

Poland (Central Vistula River valley). The oldest representatives of the kazimiroviensis group in the upper Maastrichtian of this area stem from the white opoka that is exposed at Męćmierz (Figure 2 ); this already represents the so-called Kazimierz Opoka, an informal lithostratigraphical unit of late Maastrichtian age (Figure 3) composed of siliceous chalk with rare marly and hardened limestone intercalations (Machalski, 2005a). Slightly younger deposits, inclusive of the K-Pg boundary interval, were accessible at Nasiłów quarry (now disused

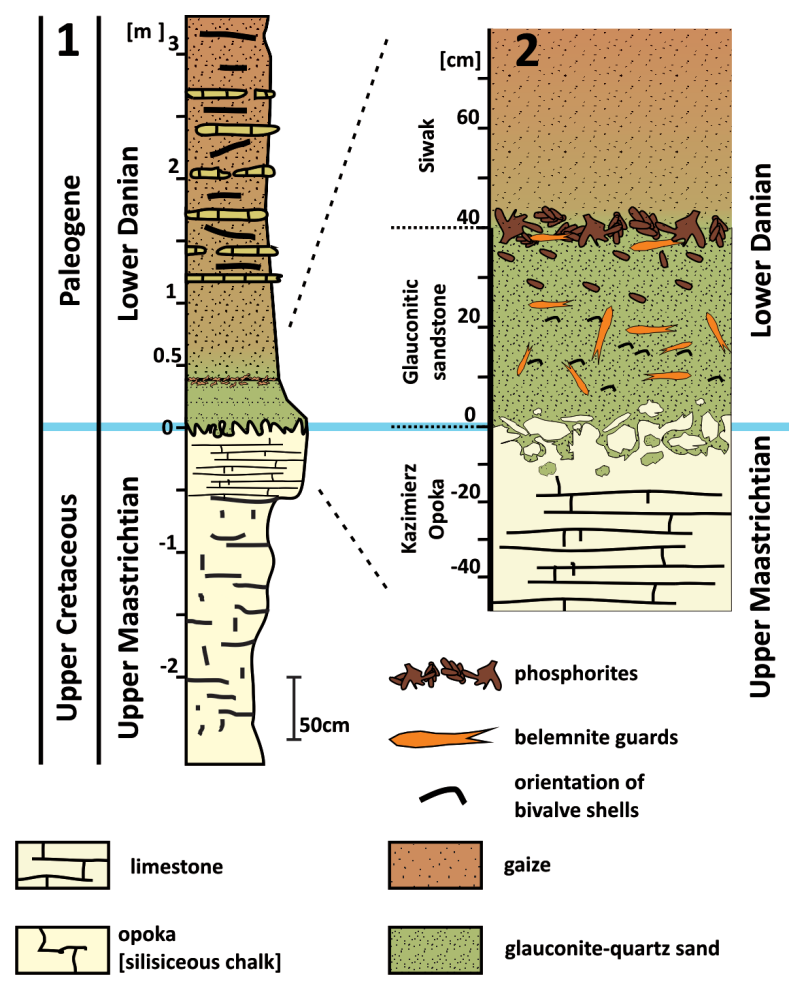

FIGURE 3. 1, Generalised K-Pg section at Nasiłów; 2, Details of the boundary interval and the position of the $\mathrm{K}-\mathrm{Pg}$ boundary placed at the top of the Kazimierz Opoka; according to Machalski (1998).

and partially recultivated), which is situated along the western bank of the River Vistula near the village of Nasiłów (Figure 2).

The section formerly exposed consisted of $c$. $14 \mathrm{~m}$ of Kazimierz Opoka in the lower part, overlain by c. $12 \mathrm{~m}$ of so-called Siwak, which comprised gaizes with intercalations of nodular limestone beds (Figure 3). Opoka and Siwak are separated by a thin, c. $40-50 \mathrm{~cm}$ thick, glauconite-rich sandstone unit with a sharp lower boundary (Figure 3), referred to in the literature as "greensand" (Machalski, 1998, 2005a). Pożaryski (1938) introduced a lithostratigraphical subdivision of Upper Cretaceous strata in the Middle Vistula River valley. In the upper Maastrichtian-lower Danian deposits, he distinguished, from bottom to top, the levels " $x "$ " upper Maastrichtian, " $y$ " - indurated limestone underlying the greensand, and " $z$ " - glauconitic sandstone.

The age and origin of this glauconitic unit have been hotly debated for years. Some authors combined the glauconitic sandstone with the overlying Siwak (compare Figure 3) and interpreted it as representing the basal, transgressive unit of an early (albeit not earliest) Danian depositional cycle (i.e., Żarski et al., 1998; Machalski, 1998, 2005a). 
Recently, Remin et al. (2015) have considered the glauconitic sandstone to be of latest Maastrichtian age, although this concept requires further study.

The Kazimierz Opoka at Nasiłów consists of siliceous chalk. The top of the unit is characterised by an up to $1 \mathrm{~m}$ thick hardened limestone with a very uneven upper surface. Apart from Bln. gr. kazimiroviensis the hard limestone has yielded the scaphitid ammonite Hoploscaphites constrictus crassus (Łopuski, 1911) (Machalski, 2005b), associated with extremely rare representatives of the pachydiscid Menuites terminus (Ward and Kennedy, 1993) and the sphenodiscid Sphenodiscus binckhorsti (Böhm, 1898) (Machalski, 2005a).

The Kazimierz Opoka is overlain by an intensively bioturbated glauconitic sandstone (up to 50 $\mathrm{cm}$ in thickness), composed of angular quartz, glauconite, and microfossil tests in a marly matrix (Machalski, 2005a). Its base is formed by an intensively burrowed limestone, whereas the top of the glauconitic sandstone is marked by a level (up to $10 \mathrm{~cm}$ thick) with abundant, fossil-bearing nodular phosphates (Figure 3). While the lower boundary of this so-called "phosphatic layer" is somewhat gradual, its upper boundary is distinct, forming the "residual lag" of Machalski and Walaszczyk (1987). Opoka-like clasts, occurring especially in the lower portion of the glauconitic sandstone, are interpreted as remnants of originally continuous layers (Kazimierz Opoka), destroyed by burrowers. They are soft and never lithified (Machalski, 1998). The glauconitic sandstone has been interpreted to be of early, albeit not earliest, Danian age, because it contains numerous fossils of Danian date in addition to latest Maastrichtian ones, and some of the latter taxa are not known as indigenous forms from the underlying Kazimierz Opoka (for a full discussion compare Machalski, 1998; see also Machalski and Walaszczyk, 1987; Świerczewska-Gładysz and Olszewska-Nejbert, 2006).

Świerczewska-Gładysz and OlszewskaNejbert (2006) recorded two assemblages of sponges from the glauconitic sandstone and the "phosphatic layer", all of them being typically Maastrichtian. Petrographic studies have indicated that the host deposit of the former assemblage was a siliceous chalk, similar to the Kazimierz Opoka, whereas the second lot originated from a now eroded glauconitic siliceous chalk unit (compare also Machalski, 1998). The latter comprises sponges that do not occur in the upper Maastrichtian Kazimierz Opoka (Świerczewska-Gładysz, 2006). The increased glauconite content, documented for the latter lot, and the faunal differences have been linked to a sea level drop towards the end of the Maastrichtian.

Of note is also the record of an external mould of Hoploscaphites constrictus cf. crassus preserved in the attachment area of the shell of a pycnodonteine oyster (tentatively identified by $M$. Machalski, February 11, 2015) from the glauconitic sandstone. This stratigraphical subspecies of $H$. constrictus is typical of a late, but not latest, Maastrichtian date (Machalski, 2005b), and as such it may imply reworking of deposits older than latest Maastrichtian and their preservation in the glauconitic sandstone.

Southeast Netherlands (Maastrichtian type area) and adjacent regions (Northeast Belgium, Western Germany). In the Maastricht area, Belemnella of the kazimiroviensis group is confined to the Meerssen Member, the highest lithostratigraphical unit of the Maastricht Formation. Where typically developed, this member comprises poorly indurated, white yellowish, coarse- to very coarsegrained chalks (biocalcarenites) with clearly developed hardgrounds and associated fossil hash layers. Its thickness ranges between c. 15 and $20 \mathrm{~m}$ (Zijlstra et al., 1996; Jagt and Jagt-Yazykova, 2012). One of the classic outcrops of the Meerssen Member is the former Curfs-Ankerpoort quarry near Geulhem, the Netherlands (Figure 4), where this unit was subdivided into seven lithological subunits, IVf-1 to IVf-7 (Figure 5). The Berg en Terblijt Horizon, which equates with the K-Pg boundary, is situated at the top of subunit IVf-6 (Jagt and JagtYazykova, 2012).

Belemnites studied here originate from the upper Meerssen Member (IVf-4 to IVf-6), from directly above the Berg en Terblijt Horizon (= base of IVf-7) and from immediately above the Vroenhoven Horizon (= base of the early-middle Danian Geulhem Member) at the following localities: ENClHeidelbergCement Group quarry (Maastricht), the Albert Canal near Vroenhoven, the former CurfsAnkerpoort quarry (Figure 5), the Geulhemmerberg subterranean galleries near Geulhem and the former Blom quarry, Berg en Terblijt.

The stratigraphically earliest representatives of the kazimiroviensis group in the Maastricht area have been recorded from the top of subunit IVf-3 or the base of IVf-4 of the Meerssen Member (Jagt, 2012b), while the oldest known population of Hoploscaphites constrictus johnjagti Machalski, 2005 is from subunits IVf-4/-5 (Machalski, 2005b; Jagt, 2012a). Another index ammonite in the middle portion of the Meerssen Member (IVf-4 and IVf-5; Jagt, 1996) is Menuites terminus with a question- 


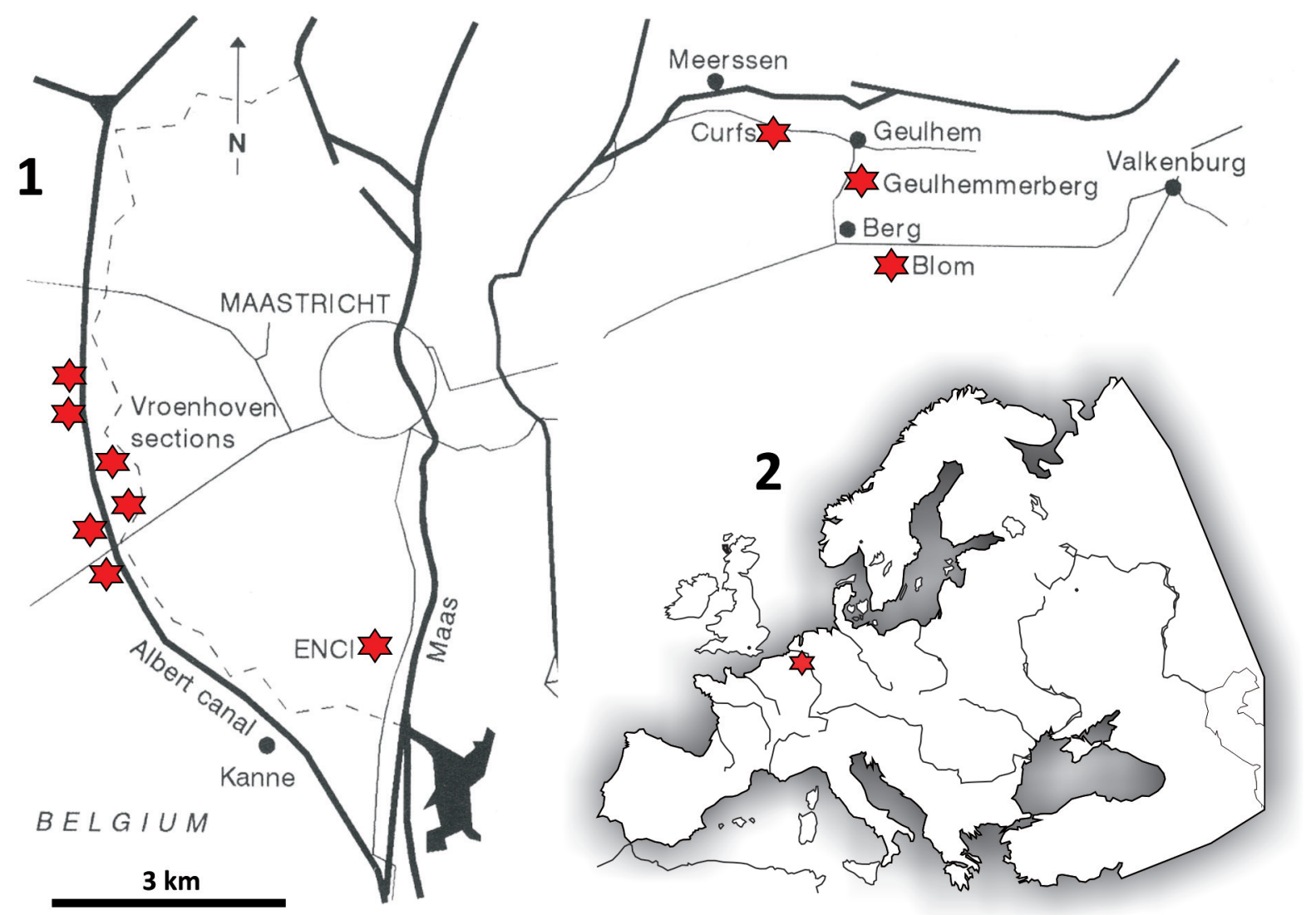

FIGURE 4. 1, Schematic map of southern Limburg (the Netherlands) showing the formerly available outcrops of the Meerssen Member (red stars) (after Jagt et al., 1996) that yielded representatives of the Belemnella kazimiroviensis group; black dots are smaller towns in the area; 2, Position of the Netherlands within Europe (red star).

able record from a level as low as the upper Nekum Member (Jagt, 2012a). The upper portion of the Meerssen Member (IVf-7) is of earliest Danian age, the K-Pg boundary corresponding to the Berg en Terblijt Horizon at the base of subunit IVf-7 (Jagt, 1996).

\section{Repositories and Description of Material}

The list of synonyms in the Systematic Palaeontology section is limited to material that can be referred without any doubt to the (sub)species. Only complete and illustrated specimens are considered. Species illustrated by the same author under the corresponding name, but not listed, either do not belong to the (sub)species or the identification is uncertain. The material analysed is housed in the collections of the Natuurhistorisch Museum Maastricht (prefix NHMM), Muzeum Ziemi, Polska Akademia Nauk, Warsaw, "Kongiel's Collection" (prefix MZ VIII Mcd). The new collection from Nasiłów is housed in the S.J. Thugutt Geolog- ical Museum, Faculty of Geology of the University of Warsaw (prefix MWGUW Zl/69/).

\section{Morphometrics}

Terminology and methods to describe guards of representatives of the genus Belemnella follow Schulz (1979) and Christensen (1995), as summarised in Keutgen et al. (2012) and are shown below (Figure 6 ). The abbreviations are as follows: AA, alveolar angle, which is the dorsoventral angle (in ${ }^{\circ}$ ) between the walls of the alveolus measured in the medium plane about $10-15 \mathrm{~mm}$ from the protoconch; $A L$, lateral aspect, $[A L=(D s-D c) \times$ $100 / \mathrm{Dp}$ (in \%)]; ALs, lateral aspect of rostrum solidum $[\mathrm{ALs}=(\mathrm{Ds}-\mathrm{Dp}) \times 100 / \mathrm{Dp}$ (in \%)]; AV, ventral aspect, $[A V=(B s-B c) \times 100 / B p($ in \%)]; AVs, ventral aspect of rostrum solidum $[A V s=(B s-B p) \times$ 100/Bp (in \%)]; Bc, lateral diameter at rostrum cavum, $1 / 4 \mathrm{Ls}$ from protoconch (in $\mathrm{mm}$ ); BI, Birkelund Index $[B \mid=L s / D p]$; Bp, lateral diameter at protoconch (in $\mathrm{mm}$ ); Bs, lateral diameter halfway between apex and protoconch (in $\mathrm{mm}$ ); Dc, dorso- 


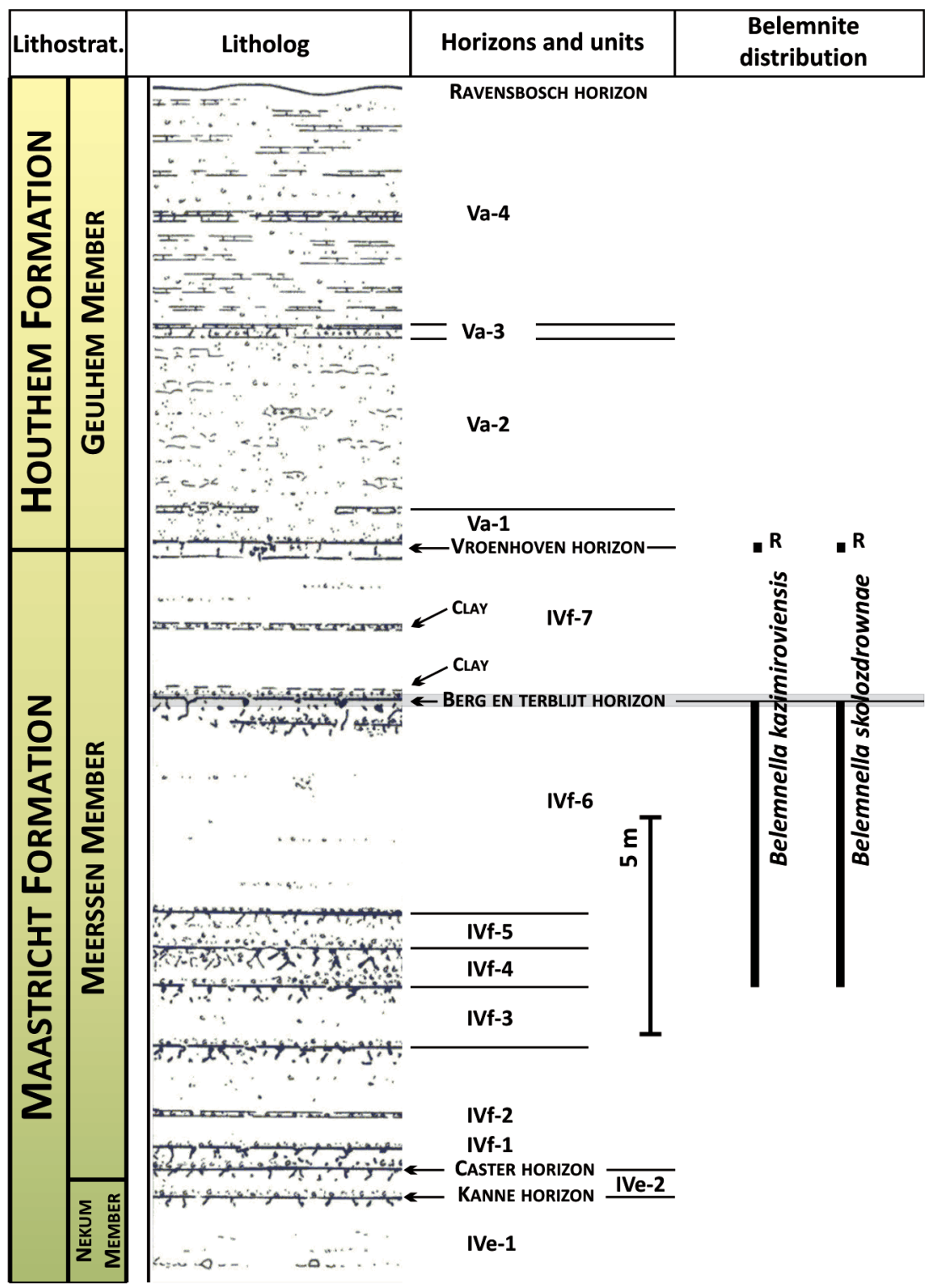

FIGURE 5. Age, lithostratigraphy, general lithology and subdivision into lithostratigraphical horizons and units (IVe-1 to Va-4) of the section formerly exposed at the Curfs-Ankerpoort quarry (Geulhem), with indication (arrow) of the KPg boundary, equating with the Berg en Terblijt Horizon at the top of subunit IVf-6 (modified after Jagt and JagtYazykova, 2012). The range of belemnite species shown is that for the entire Maastricht area. $R=$ remanié specimens.

ventral diameter at rostrum cavum, $1 / 4 \mathrm{Ls}$ from protoconch (in $\mathrm{mm}$ ); $\mathbf{D p}$, dorsoventral diameter at protoconch (in $\mathrm{mm}$ ); Ds, dorsoventral diameter halfway between apex and protoconch (in $\mathrm{mm}$ ); FA, fissure angle, which is the angle (in ${ }^{\circ}$ ) between the wall of the alveolus and the straight line connecting the intersection points of the bottom of the ventral fissure on the wall of the alveolus and the outer margin of the guard; Ls, length from apex to protoconch (in $\mathrm{mm}$ ); SD, Schatzky Distance, the distance (in $\mathrm{mm}$ ) between the midpoint of the pro- toconch and the posterior end of the ventral fissure measured along the axis of the guard.

The parameters Lsn and WQs for early Maastrichtian species were described by Schulz (1979) as follows: Lsn, standardised length form apex to the protoconch, $[\mathrm{Lsn}=\mathrm{Ls}+\mathrm{WQs} \times($ mean Dp $\mathrm{Dp}$ ) (in $\mathrm{mm}$ )]; WQs, ontogenetic growth quotient of individual guards, $[\mathrm{WQs}=(\mathrm{Ls} 2-\mathrm{Ls} 1) /(\mathrm{Dp} 2-\mathrm{Dp} 1)$ with $\mathrm{Dp} 2>\mathrm{Dp} 1>6 \mathrm{~mm}$ ]. However, as discussed below, their calculation was modified for Bln. gr. kazimiroviensis. 


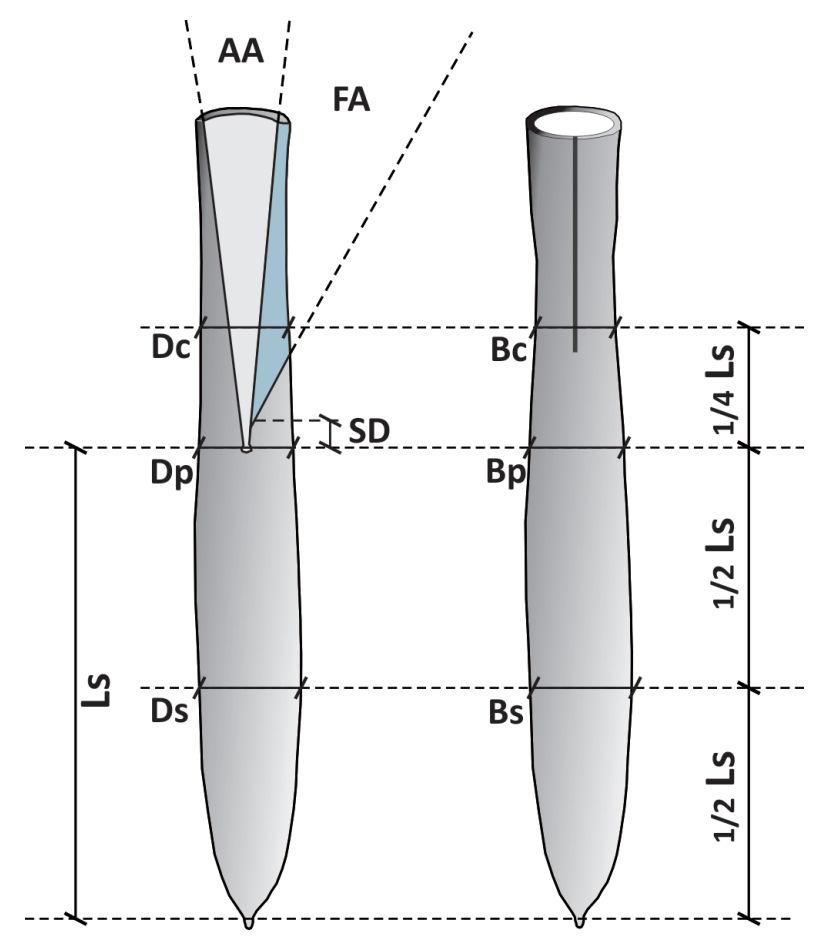

FIGURE 6. Diagram illustrating morphological features of the belemnite guard (lateral view of a longitudinally split guard on the left, ventral view on the right). $A A=$ alveolar angle; FA = fissure angle; SD = Schatzky distance; Ls = length from apex to protoconch; Ds, Dp, Dc $=$ dorso-ventral diameters at different part of the rostrum; Bs, Bp, Bc = lateral diameters at different part of the rostrum (after Keutgen, 1997; Keutgen et al., 2012).

The following categories for size and shape of guards of the genus Belemnella are distinguished: length from apex to protoconch $<55 \mathrm{~mm}$ - small guard; length between 55 and $65 \mathrm{~mm}$ - large guard; length between 65 and $75 \mathrm{~mm}$ - very large guard; length > $75 \mathrm{~mm}$ - extraordinary large guard; $\mathrm{AV}$ and AL larger than $30 \%$ - distinctly lanceolate shape; AV and AL between 10 and $30 \%$ - slightly lanceolate shape; $\mathrm{AV}$ and $\mathrm{AL}$ between -10 and $10 \%$ - subcylindrical shape; AV and AL between 30 and $-10 \%$ - subconical shape; AV and AL smaller than $-30 \%$ - conical shape.

\section{RESULTS}

\section{Size-Group Distribution of Latest Maastrichtian Populations of the kazimiroviensis Group}

In order to investigate the distribution of size groups (as defined by the dorsoventral diameter at the protoconch), larger amounts of sediment from both the glauconitic sandstone and the basal Siwak at Nasiłów were examined in detail using a 2 $\mathrm{mm}$ mesh sieve, and each belemnite fragment was collected. Although the amount of sediment studied was different for each interval, on account of the thickness of the corresponding layers, the relative distribution of size classes should be reflected. It is noteworthy that since fragments, irrespective of completeness and preservational state, were examined, the dorsoventral diameter at the protoconch (Dp) could rarely be measured. In case of fragments of the rostrum solidum or rostrum cavum, the dorsoventral diameter was measured at the end nearest to the protoconch in order to obtain the best possible approximation.

At Nasiłów, belemnites were collected from the glauconitic sandstone below the "phosphatic layer", from the "phosphatic layer" and from the sandy gaize, immediately above "phosphatic layer" (Figure 3). Since the values of the dorsoventral diameters (mean, median, standard deviation, maximum, and minimum values) recorded are fairly similar (Table 1), all data form Nasiłów were lumped (Figure 7). Of note is that the mean dorsoventral diameter of representative specimens from sieve residues is about $25 \%$ smaller than that calculated for completely preserved specimens used for population analysis of BIn. kazimiroviensis from the glauconitic sandstone (see below).

For comparison, belemnites were collected from distinct levels in the Maastricht area. These either came from immediately above the K-Pg boundary (i.e., Berg en Terblijt Horizon) in the underground galleries at the Geulhemmerberg, or from just above the Vroenhoven Horizon exposed at the Albert Canal section near Vroenhoven, which rests directly on subunit IVf- 6 of the Meerssen Member. It should be stressed that the subterranean galleries had been sampled before by other collectors, which means that our collection is biased, because larger specimens of Bln. gr. kazimiroviensis might already have been selectively removed. Our sample from the Albert Canal section near Vroenhoven was biased as well, because very small specimens were not collected; this is seen in the minimum value recorded here (Table 1). Despite these drawbacks, the mean and median values of populations from Poland and the Netherlands/Belgium are surprisingly similar. In fact, mean and, in particular, median values of specimens from the Maastricht area are even smaller than those from Nasiłów, although these had not been collected by sieving. It might be added here that from above the Vroenhoven Horizon exposed at the former Curfs quarry an accumulation of usually very small fragments of Bln. gr. 
TABLE 1. Distribution of size groups of the stratigraphically youngest populations of Bln. gr. kazimiroviensis from Nasiłów (Poland) and from the Geulhemmerberg and Albert Canal sections near Maastricht (the Netherlands, Belgium). SD: standard deviation, N: number of specimens.

\begin{tabular}{|c|c|c|c|c|c|c|c|}
\hline & $\begin{array}{c}\text { Nasiłów, } \\
\text { glauconitic } \\
\text { sandstone - } \\
\text { below } \\
\text { "phosphatic } \\
\text { layer" }\end{array}$ & $\begin{array}{c}\text { Nasiłów, } \\
\text { glauconitic } \\
\text { sandstone, } \\
\text { "phosphatic } \\
\text { layer" }\end{array}$ & $\begin{array}{c}\text { Nasiłów, basal } \\
\text { Siwak } \\
\text { (immediately } \\
\text { above } \\
\text { "phosphatic } \\
\text { layer") }\end{array}$ & $\begin{array}{c}\text { Nasiłów, } \\
\text { glauconitic } \\
\text { sandstone } \\
\text { and basal } \\
\text { Siwak }\end{array}$ & $\begin{array}{l}\text { Maastricht, } \\
\text { Geuhemmer- } \\
\text { berg, above } \\
\text { Berg en Terblijt } \\
\text { Horizon }\end{array}$ & $\begin{array}{l}\text { Maastricht, } \\
\text { Albert Canal, } \\
\text { above } \\
\text { Vroenhoven } \\
\text { Horizon }\end{array}$ & $\begin{array}{c}\text { Maastricht, } \\
\text { Geuhemmer- } \\
\text { berg \& Albert } \\
\text { Canal }\end{array}$ \\
\hline Mean & 7.8 & 7.4 & 8 & 7.6 & 7.1 & 7.5 & 7.4 \\
\hline Median & 7.9 & 7.4 & 7.2 & 7.8 & 6.7 & 6.8 & 6.8 \\
\hline SD & 2.8 & 3.1 & 4.1 & 3.1 & 3.3 & 2.4 & 2.6 \\
\hline Max & 12.6 & 13.2 & 14.1 & 14.1 & 14.3 & 14.4 & 14.4 \\
\hline Min & 3 & 2 & 3.3 & 2 & 2.5 & 4.7 & 2.5 \\
\hline$N$ & 27 & 31 & 9 & 67 & 10 & 27 & 37 \\
\hline
\end{tabular}

kazimiroviensis was recorded; this could not be collected because of current inaccessibility of the site.

A comparison of the relative size-distributions of the stratigraphically youngest representatives of Bln. gr. kazimiroviensis from the central Vistula River valley and the Maastricht area revealed that the majority of specimens (c. $30 \%)$ are in the range of 4-6 $\mathrm{mm}$ for the dorsoventral diameter in both areas (Figures 7 and 8 ). In Poland, there appears to be a greater proportion of specimens with $>10$ $\mathrm{mm}$ diameter (c. $25 \%$ ) than in the Netherlands/Belgium (c. 16\%).

\section{Statistics}

For the present study of latest Maastrichtian guards of the genus Belemnella only (near-) complete specimens were considered. First of all, the ontogenetic growth quotient WQs of individual guards was determined as proposed by Schulz (1979). It could be measured on five specimens from the Middle Vistula River valley and on two from Maastricht. In addition, the WQs of another seven specimens were deduced from material illustrated in the literature (Jeletzky, 1951; Birkelund, 1957; Naidin, 1975). The mean value of WQs of all specimens with a Dp1 $>5.0 \mathrm{~mm}$ is 3.70 ,

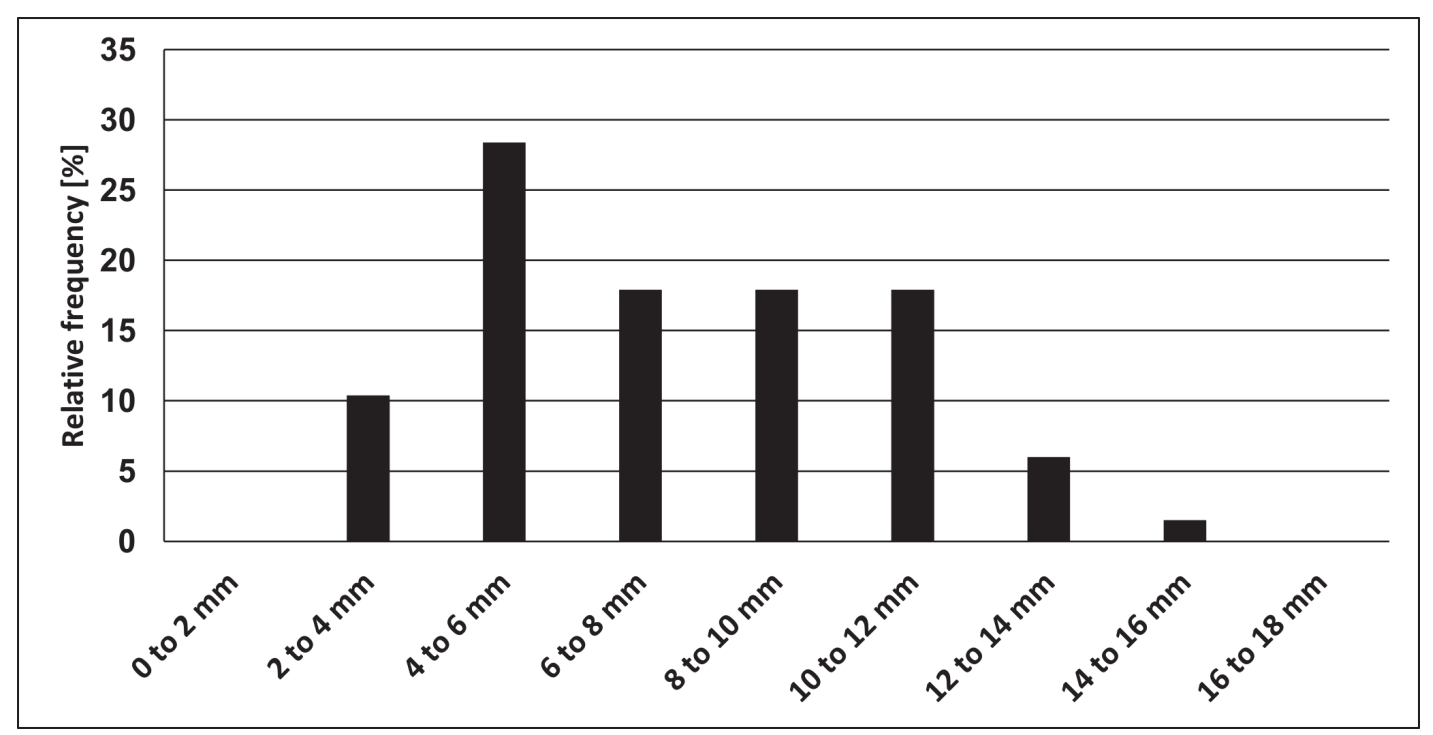

FIGURE 7. Relative distribution of size groups of Bln. gr. kazimiroviensis from the glauconitic sandstone and basal Siwak at Nasiłów (Poland). 


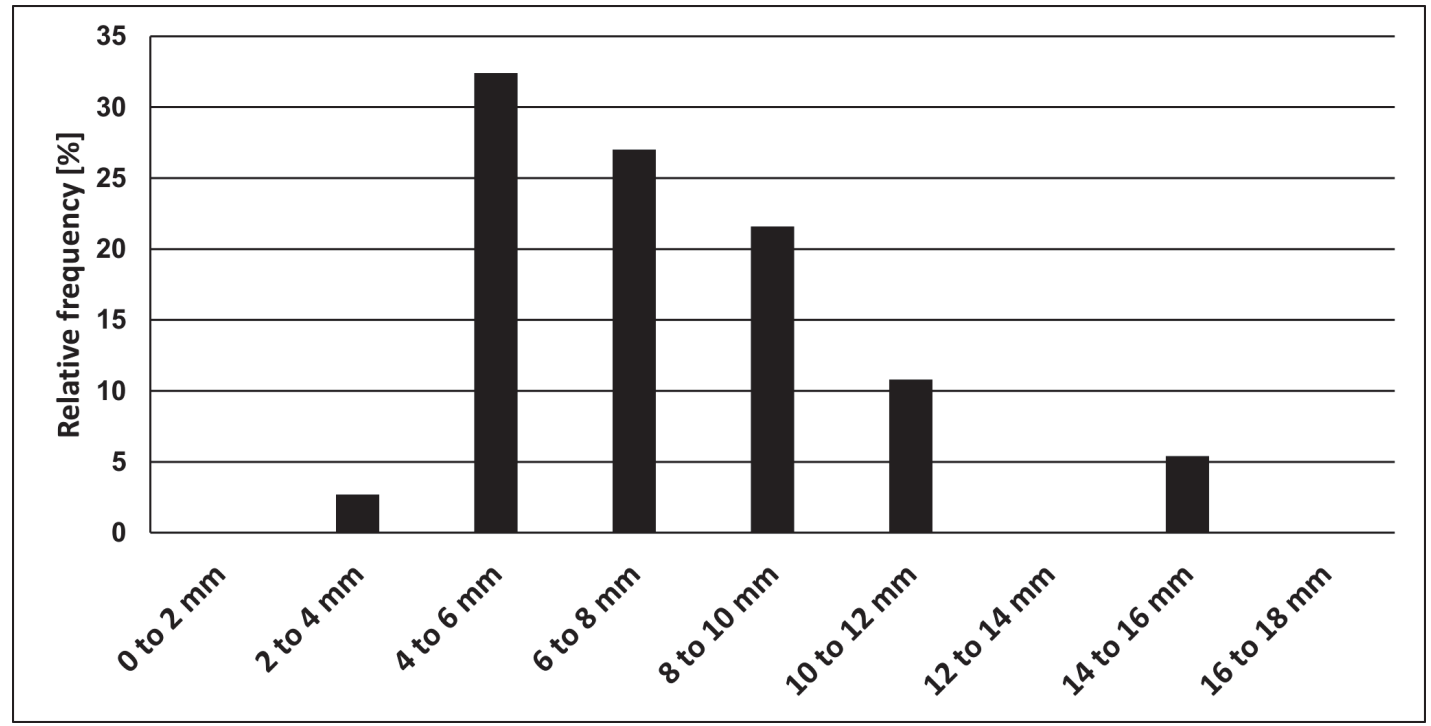

FIGURE 8. Relative distribution of size groups of Bln. gr. kazimiroviensis from the Maastricht area - Geulhemmerberg underground section above the Berg en Terblijt Horizon (the Netherlands) and Albert Canal sections above the Vroenhoven Horizon (Belgium).

which figure has been used for the calculation of Lsn (sensu Schulz, 1979). For the calculation of Lsn also the mean dorsoventral diameter at protoconch $\mathrm{Dp}$ is needed, which has been determined on the basis of measured specimens from the Vistula River valley and from Maastricht; it is $9.9 \mathrm{~mm}$. The Lsn of Bln. gr. kazimiroviensis calculated in line with Schulz (1979) is, hence,

$$
\text { Lsn }=\text { Ls }+3.70 \times(9.9-\mathrm{Dp})(\text { in } \mathrm{mm})
$$

While the WQs of Schulz (1979) is based merely on a limited number of specimens, an alternative procedure has been developed by studying the relationship of $\mathrm{BI} v s \mathrm{Dp}$ (Figure 9). Here, all data of specimens studied are plotted, inclusive of measurements of early ontogenetic stages in longitudinally split specimens. The growth relationship

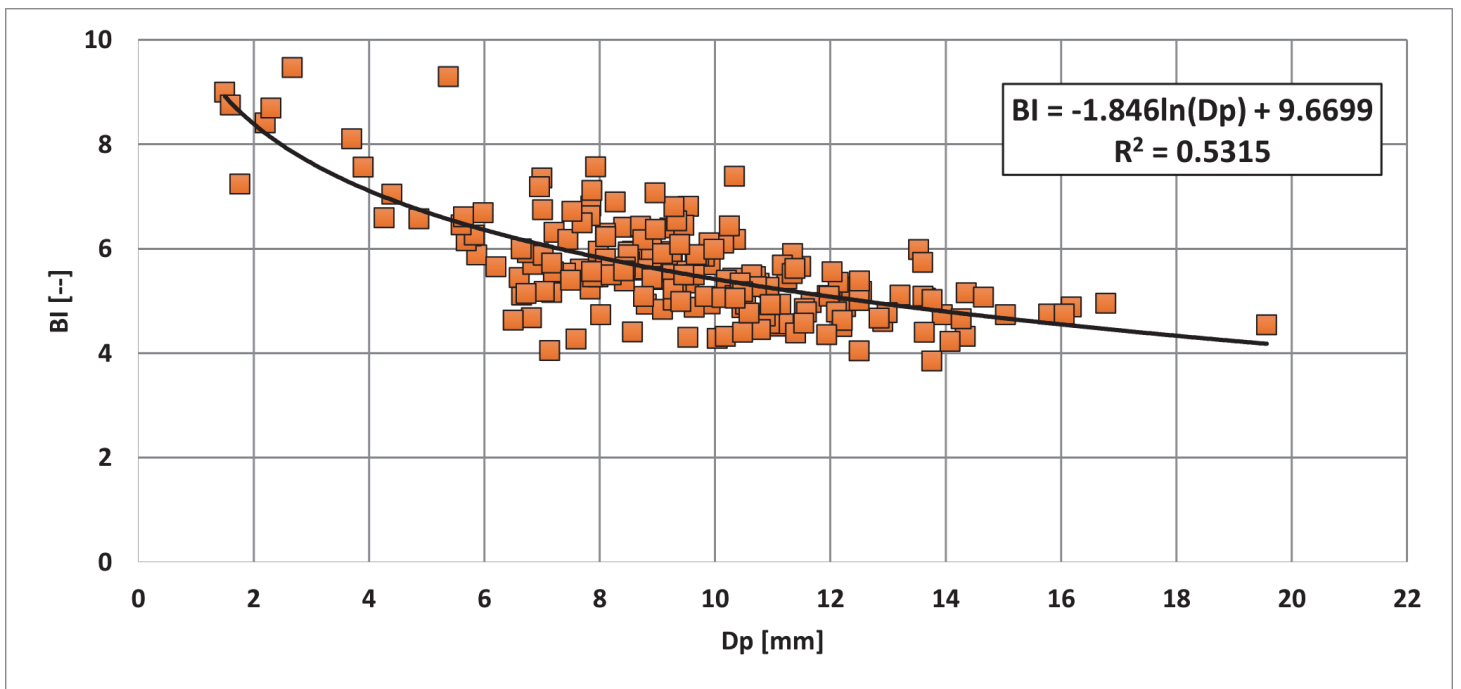

FIGURE 9. Relationship of BI (Birkelund Index) vs Dp (dorso-ventral diameter at the protoconch) $(\mathrm{BI}=\mathrm{Ls} / \mathrm{Dp}$; compare with Figure 6) of all guards of the kazimiroviensis group from the Middle Vistula River valley, the Maastricht area, Denmark, central and southern Russia and Central Asia, inclusive of data of early ontogenetic stages measured on longitudinally split specimens. The growth relationship is best described by a logarithmic curve, indicating that small (young) specimens are relatively more slender than larger (adult) ones. 


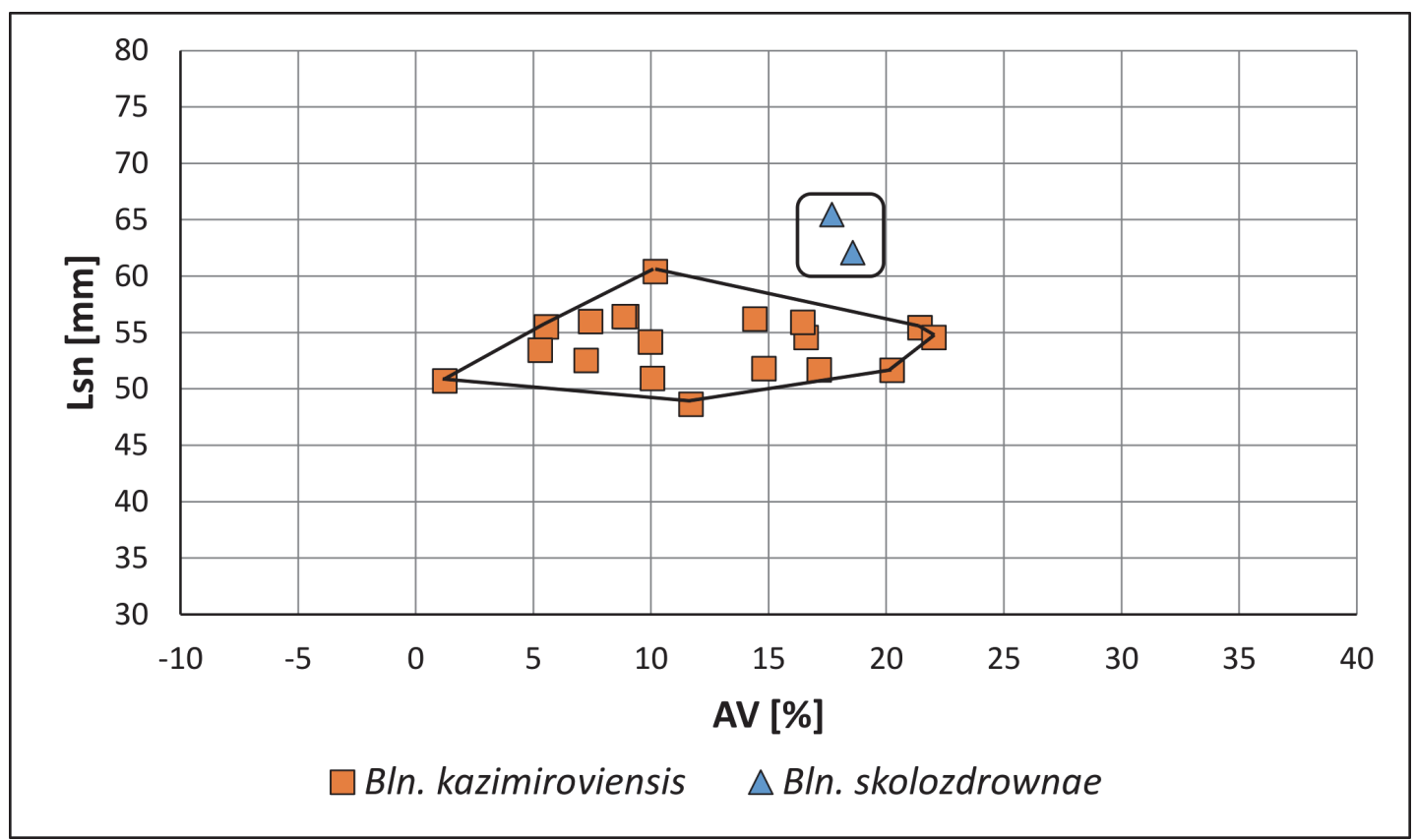

FIGURE 10. Two-dimensional plot Lsn (standardised length form apex to the protoconch) vs. AV (ventral aspect) of guards of Bln. kazimiroviensis and Bln. skolozdrownae from the Kazimierz Opoka (Kongiel Collection) from different localities (Kazimierz, Bochotnica and Nasilów), all except one from levels x and y sensu Pożaryski (1938).

is best described by a logarithmic curve, indicating that small (young) specimens are relatively more slender than larger (adult) ones. From the equation,

$$
B I=-1,846 \ln (D p)+9.6699
$$

Bl-values for $\mathrm{Dp} 1=5 \mathrm{~mm}$ and $\mathrm{Dp} 2=16 \mathrm{~mm}$ can be calculated, thus covering the majority of specimens. From the derived values of $\mathrm{BI} 1$ and $\mathrm{BI} 2$ Lsn1 and Lsn2 can be calculated using the relationship Lsx = Blx x Dpx, which can be used for the calculation of an "alternative WQs" based on a population of belemnites. For all specimens of BIn. gr. kazimiroviensis the "alternative WQs" equals 3.58 , which is close to the value of 3.70 calculated from single, longitudinally split specimens. However, Figure 9 also indicates that the calculation of the "alternative WQs" depends strongly of the interval Dp1 - Dp2 chosen. If, for instance, in the present example Dp2 $=20 \mathrm{~mm}$ is used, the calculated "alternative WQs" is reduced to 3.29.

Based on this observation, the Lsn parameter was calculated (referred to a mean Dp (Dpn) of 9.9 $\mathrm{mm}$ ) for Bln. gr. kazimiroviensis on the basis of the following equation:

Lsn = Dpn x BIn = $9.9 \times(5.44+(B I-(-1.846 \ln (D p)+9.6699)))$ (in $\mathrm{mm}$ )

The so-calculated Lsn has been used for the identification of species. However, since two species,
Bln. kazimiroviensis and Bln. skolozdrownae, were identified (Figure 10), the relationship BI vs Dp was recalculated for either species separately, and new Lsn values were calculated for each specimen using the improved relationship (see below). These values were used for population statistics and are here presented in the illustrations.

All specimens of Bln. gr. kazimiroviensis from the Middle Vistula River valley and Maastricht areas were subjected to a principal component analysis (PCA) using the parameters $\mathrm{Dp}, \mathrm{SW}, \mathrm{AA}$, FA, Lsn, and AV. Ls was not included, because the coefficient of determination $\left(r^{2}, r=\right.$ Pearson correlation coefficient) between Ls and Dp was 0.64. Ls is, first of all, a size-dependent parameter similar to Dp. In addition, Ls may contain information on the slenderness of the guard. This information is, however, better described by the parameters Lsn and $\mathrm{BI}$, the coefficient of determination between the latter being 0.70 . Here, the Lsn is used, rather than $\mathrm{BI}(=\mathrm{Ls} / \mathrm{Dp})$, because the relationship between Ls and $D p$ is not approximately linear in the genus Belemnella, resulting in a distinct size-dependency of the parameter $\mathrm{BI}$. In addition, the shape values ( $A V, A L, A V s, A L s)$ are significantly related to each other, as indicated by their coefficients of determination ranging between 0.65 and 0.83 . As a consequence, only a single shape parameter (AV) was included into the PCA. 
TABLE 2. Principal components (PC) co-ordinates of the variables, based on correlations (PCA). See the section Morphometrics of Material and Methods for measurement abbreviations.

\begin{tabular}{lcccccc}
\hline & PC 1 & PC 2 & PC 3 & PC 4 & PC 5 & PC 6 \\
\hline Dp & 0.433 & -0.662 & 0.374 & 0.362 & -0.227 & -0.227 \\
SW & 0.46 & 0.021 & -0.836 & 0.101 & -0.263 & -0.097 \\
AA & -0.148 & 0.764 & 0.171 & 0.585 & -0.107 & -0.104 \\
FA & -0.788 & 0.087 & 0.07 & -0.391 & -0.33 & -0.321 \\
Lsn & -0.778 & -0.304 & -0.094 & 0.266 & -0.261 & 0.392 \\
AV & -0.713 & -0.311 & -0.323 & 0.305 & 0.365 & -0.252 \\
\hline
\end{tabular}

The parameters Dp, SW, AA, FA, Lsn, and AV were subjected to a PCA using the statistical program Statistica version 10 . The loading matrix is shown in Table 2.

Especially the contribution of FA, Lsn and AV to PC 1 is large (Table 2). To PC 2 especially AA and Dp contribute, while SW contributes most to PC 3. The remaining principal components are not clearly defined and probably are less important, although they contribute $27.3 \%$ to the cumulative total variance of the data (Table 3).

A comparison of the distribution of the data points determined by PC 1 and PC 2 of specimens from the Middle Vistula valley and the Maastricht area arranged on an $x-y$ co-ordinate system indicated, firstly, that the specimens from the glauconitic sandstone are characterised by a larger variation than those from the Kazimierz Opoka and the Maastricht area, the latter with two exceptions. Secondly, that the differences in the range of variation occur only in PC 1 (Figure 11). A similar figure resulted from a combination of PC 1 and PC 3 (results not shown). The fact that the range of variation of specimens from the glauconitic sandstone is larger than that known from other localities and/ or stratigraphical levels in the Middle Vistula valley is considered typical of the presence of more than one species at that level (compare Schulz, 1979).

Due to the result of the PCA, that the difference between species is contained only in the information that characterises $P C 1$, it was decided to analyse FA, Lsn, and AV separately, and to create one three-dimensional and three two-dimensional plots. According to one of us (NK), the distribution of belemnite guards and, as a consequence, the assignment of specimens to species, is best reflected by the combination of AV vs. Lsn, with FA being the decisive character when the ranges of species overlap. This concept for the identification of specimens of the kazimiroviensis group is almost identical with that of Schulz (1979), who distinguished early Maastrichtian species of the genus Belemnella based on their AV and Lsn values only. However, discrimination of species would also be possible using PC 1 and 2 of the PCA, but the classification of single specimens might turn out to be different. Nevertheless, using similar parameters for early and late Maastrichtian species of Belemnella, viz., AV, and Lsn, for the identification of species is preferable, in particular with respect to studies on the origin of late Maastrichtian species of Belemnella.

\section{Comparison of Populations of the kazimiroviensis Group}

Kazimierz Opoka. The oldest specimens of Bln. gr. kazimiroviensis from the Middle Vistula valley are known from the Kazimierz Opoka. The sample contained two species, with the majority belonging

TABLE 3. Eigenvalues of correlation matrix and related statistics of the PCA.

\begin{tabular}{cccc}
\hline PC & Eigenvalue & $\begin{array}{c}\text { Total } \\
\text { variance [\%] }\end{array}$ & $\begin{array}{c}\text { Cumulative total } \\
\text { variance [\%] }\end{array}$ \\
\hline 1 & 2.16 & 35.97 & 35.97 \\
2 & 1.22 & 20.32 & 56.29 \\
3 & 0.99 & 16.44 & 72.73 \\
4 & 0.8 & 13.35 & 86.08 \\
5 & 0.44 & 7.38 & 93.46 \\
6 & 0.39 & 6.54 & 100 \\
\hline
\end{tabular}




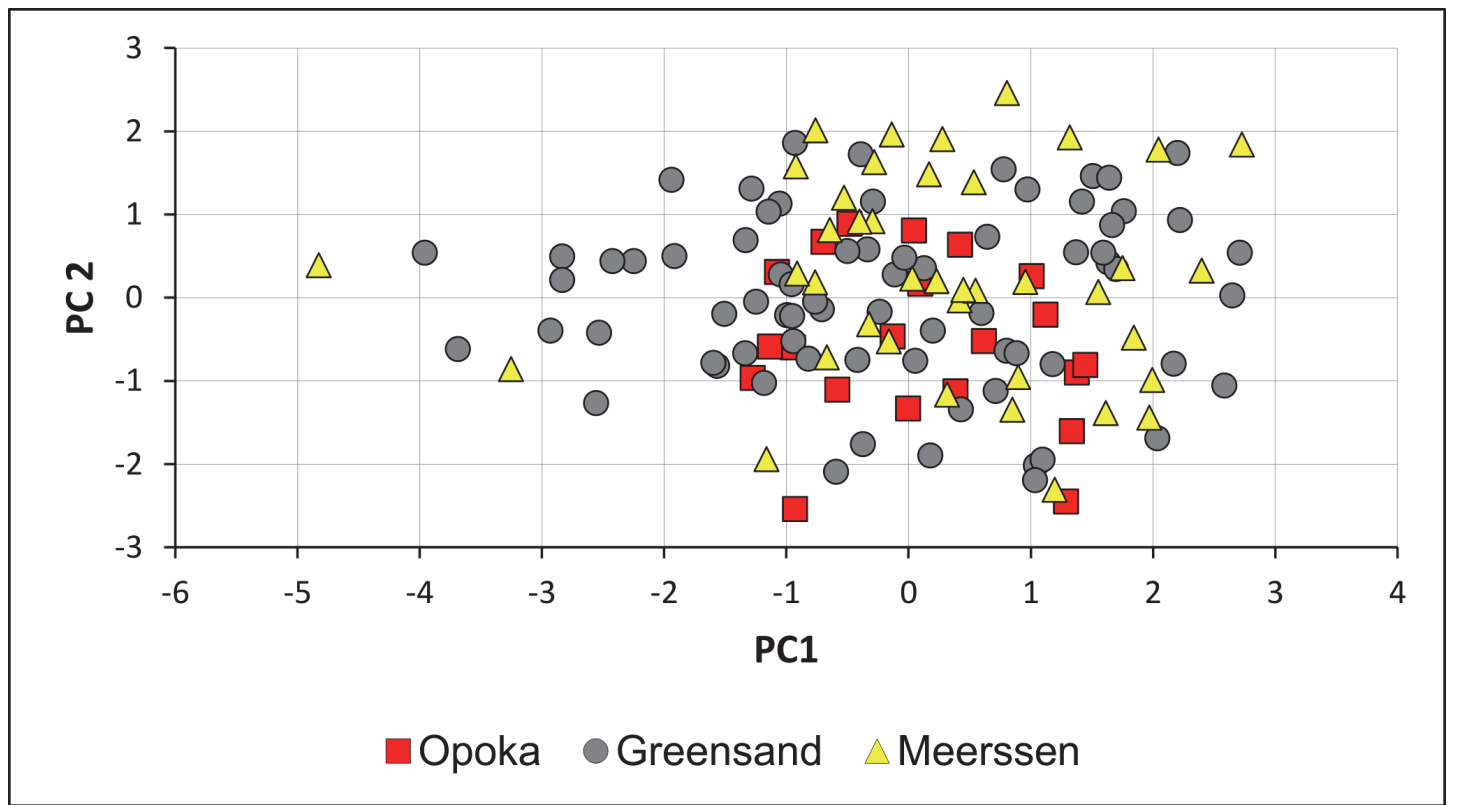

FIGURE 11. Two-dimensional plot for PC 1 and PC 2 derived from the PCA of belemnites of the kazimiroviensis group of the Kazimierz Opoka (Opoka) and the glauconitic sandstone (Greensand) of the Middle Vistula valley, as well as of those from the Maastricht area (the Netherlands, Belgium) (Meerssen).

to Bln. kazimiroviensis, but two specimens are interpreted as Bln. skolozdrownae (Figure 10).

Glauconitic sandstone at Nasiłów. Initially, specimens from the "greensand" that separates the Kazimierz Opoka and Siwak at Nasiłów quarry have been subdivided into two subsamples from the "phosphatic layer" and from the "greensand" below the "phosphatic layer". Because differences in the belemnite contents of both subsamples were not detected, these specimens were lumped (Figure 12). The majority of specimens from the Kazimierz Opoka are referred to as BIn. kazimiroviensis. A second, smaller group of specimens belongs to Bln. skolozdrownae.

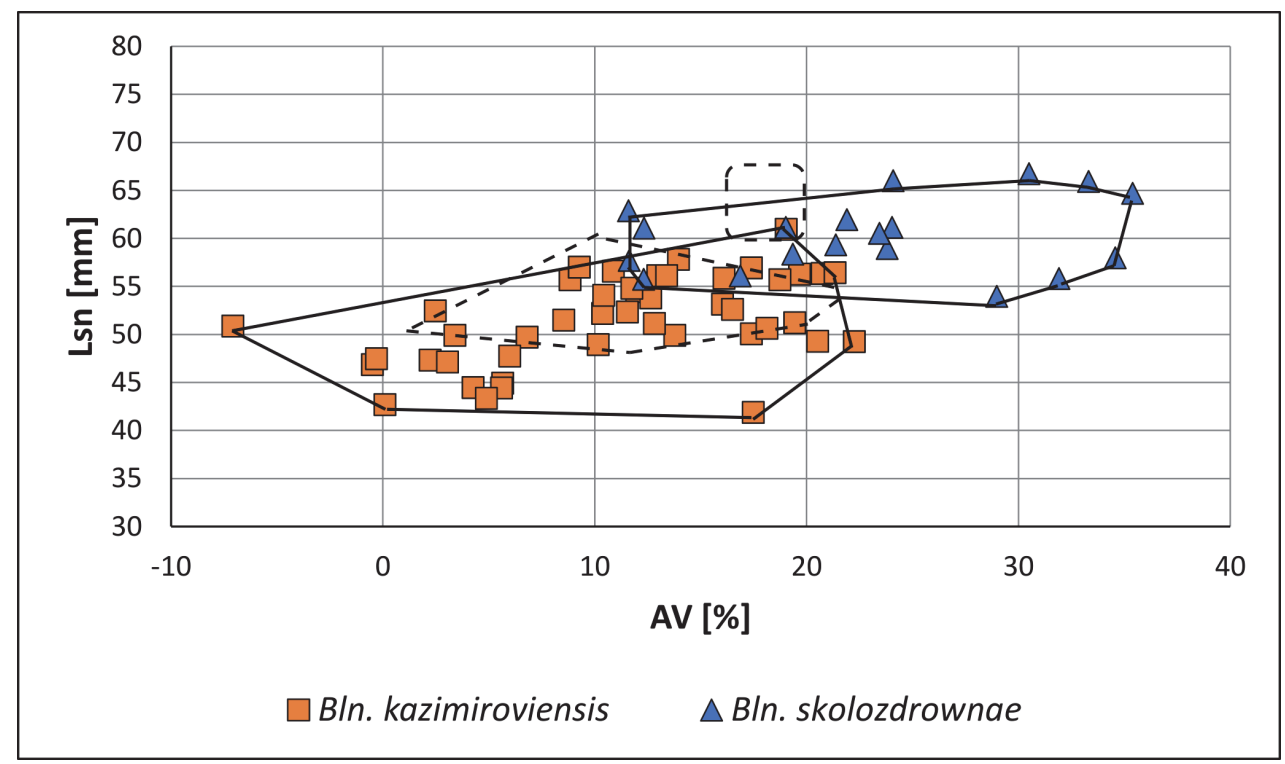

FIGURE 12. Two-dimensional plot Lsn (standardised length form apex to the protoconch) vs. AV (ventral aspect) of guards of Bln. kazimiroviensis and Bln. skolozdrownae from the glauconitic sandstone at Nasilów quarry. The dashed line indicates the variability of both species in the stratigraphically older Kazimierz Opoka. 


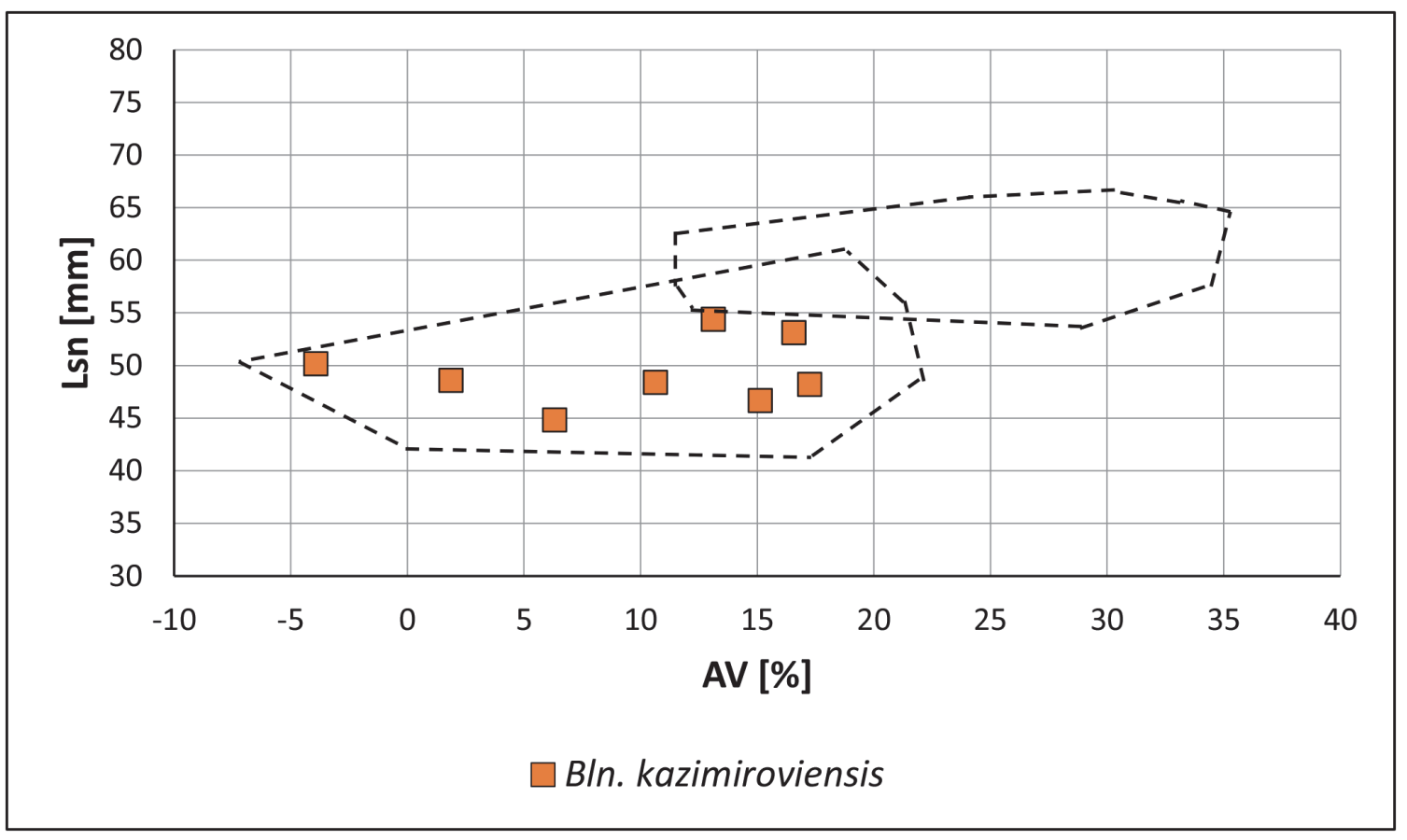

FIGURE 13. Two-dimensional plot Lsn (standardised length form apex to the protoconch) vs. AV (ventral aspect) of guards of Bln. kazimiroviensis from the basal Siwak at Nasilów quarry. The dashed lines indicate the variability of Bln. kazimiroviensis and Bln. skolozdrownae from the stratigraphically older glauconitic sandstone.

The Basal Siwak at Nasiłów. A small lot of Bln. kazimiroviensis was collected from just above the "residual lag" (= "phosphatic layer"). These specimens plot within the range of Bln. kazimiroviensis from the glauconitic sandstone and are referred to this species (Figure 13). Belemnella skolozdrownae is not present, which may be a reflection of small sample size.

Representatives of Bln. kazimiroviensis from the basal Siwak do not differ in the range of variation of AV and Lsn from those of the glauconitic sandstone, but the alveolar angles of these specimens demonstrate relatively large values between $19^{\circ}$ and $20^{\circ}$. It is not known yet whether this difference is taxonomically and stratigraphically important.

The inner alveolar parts of two of the specimens mentioned here (ZI/69/037, ZI/69/89) were filled with an opoka-like, marly material. Consequently, it may be concluded that they were reworked from underlying Maastrichtian deposits. This may also hold true for the other six specimens.

The Upper Meerssen member, inclusive of the Vroenhoven Horizon, in the Maastricht area. Belemnites of the kazimiroviensis group from the Maastricht area can be subdivided into two groups. The first, larger one, may be referred to as Bln. kazimiroviensis and the second, consisting of three specimens, as Bln. skolozdrownae (Figure 14). One incomplete specimen of the latter form from Maastricht is characterised by an unusually large Lsn value of c. $80 \mathrm{~mm}$ and a rather lanceolate shape in lateral view. It is considered an extreme, possibly pathological, form of this species.

Belemnites from central and southern Russia and Central Asia. Data on specimens mentioned here are deduced from literature sources (Jeletzky, 1951; Naidin, 1975; Alekseev et al., 1999; Naidin and Beniamovski, 2006) in order to enable a preliminary comparison of the western and central European species of the kazimiroviensis group with those of central and southern Russia and Central Asia. In view of the fact that for some specimens outlined by Naidin (1975) only the lateral view is presented, the shape in ventral view (AV) was estimated taking into account the strong relationship among shape parameters. Still, this procedure emphasises the preliminary character of our comparison.

The majority of specimens from central and southern Russia and Central Asia plot well within the range of Bln. kazimiroviensis known from the Middle Vistula valley and the Maastricht area (Figure 15). However, subcylindrical guards with AV values $<5 \%$ are absent. Another feature of this 


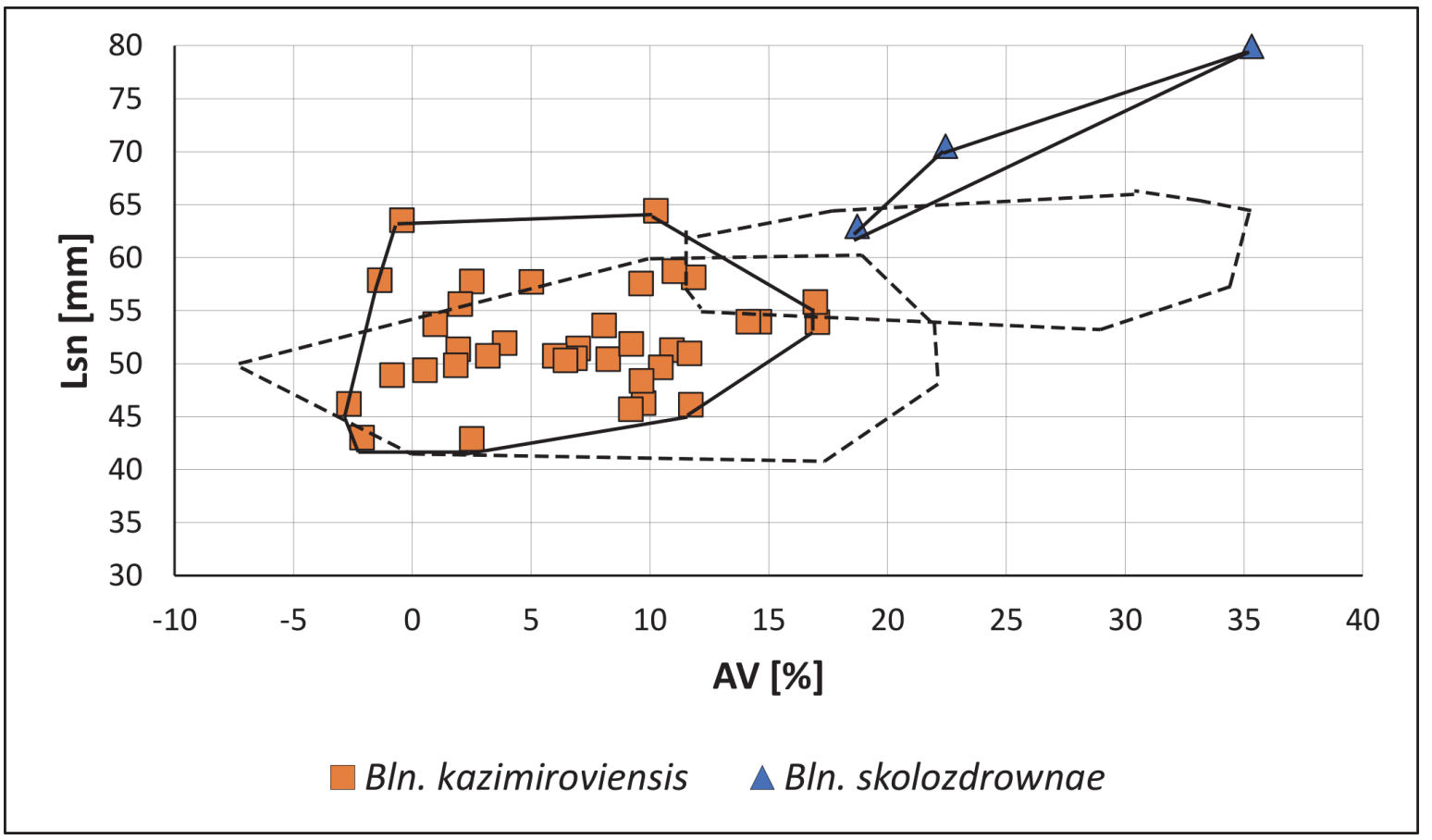

FIGURE 14. Two-dimensional plot Lsn (standardised length form apex to the protoconch) vs. AV (ventral aspect) of guards of Bln. kazimiroviensis and Bln. skolozdrownae from deposits in the Maastricht area (the Netherlands, Belgium). The dashed lines indicate the variability of Bln. kazimiroviensis and BIn. skolozdrownae from the Middle Vistula valley region (Poland).

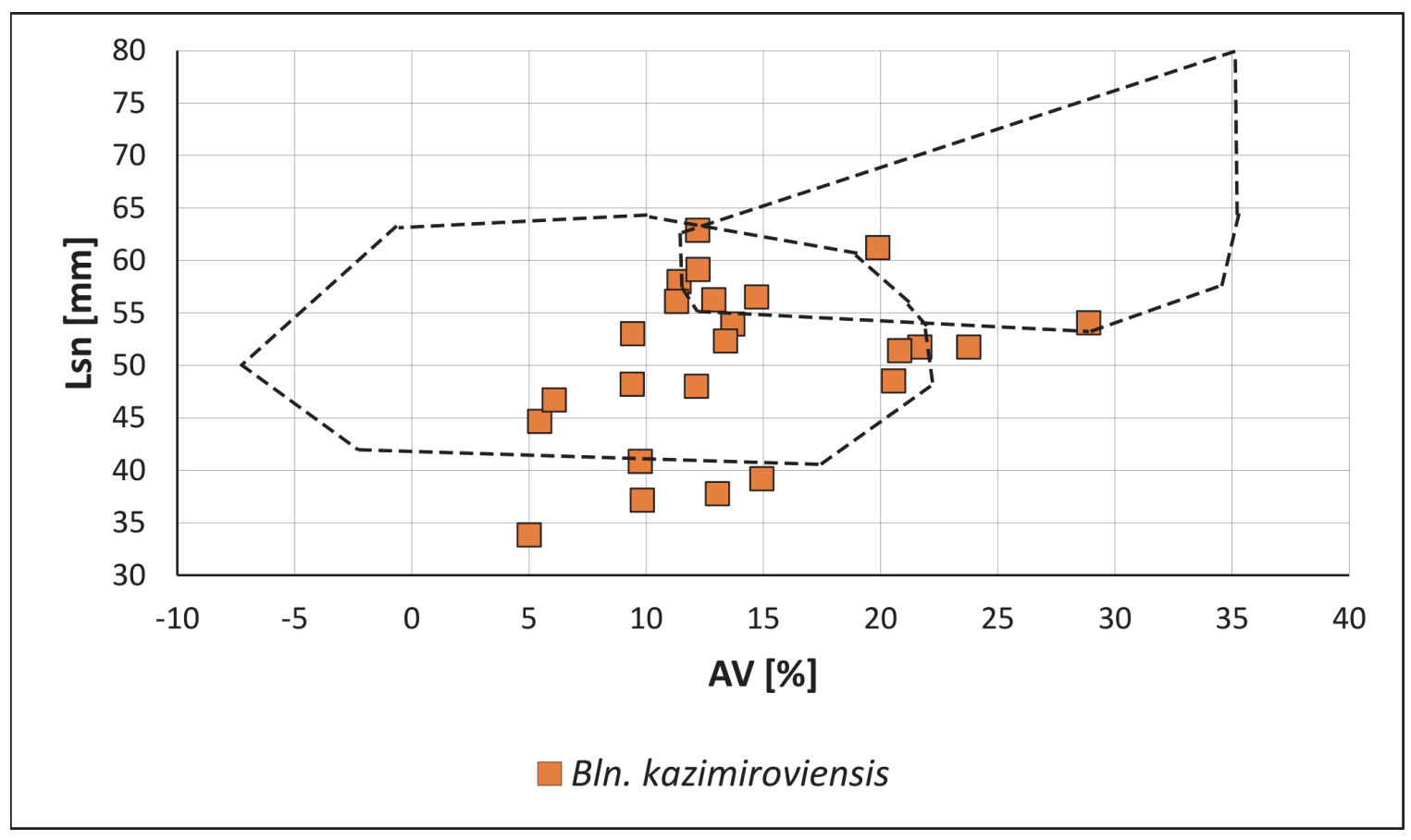

FIGURE 15. Two-dimensional plot Lsn (standardised length form apex to the protoconch) vs. AV (ventral aspect) of guards of Bln. kazimiroviensis from central and southern Russia and Central Asia, as illustrated by Naidin (1975). The dashed lines indicate the variability of Bln. kazimiroviensis and Bln. skolozdrownae from the Maastricht and the Middle Vistula valley regions. 


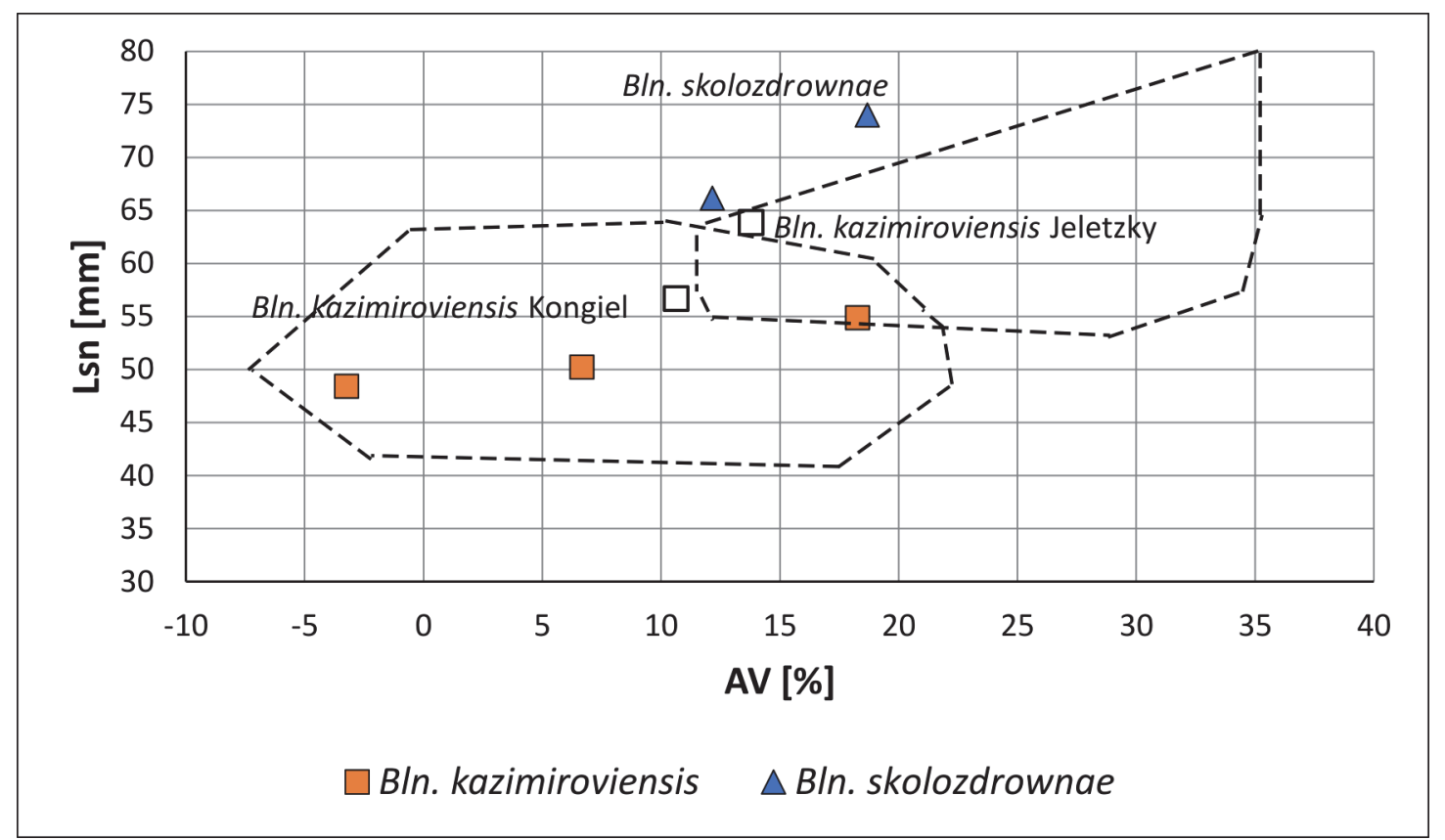

FIGURE 16. Two-dimensional plot Lsn (standardised length form apex to the protoconch) vs. AV (ventral aspect) of guards of Bln. kazimiroviensis and Bln. skolozdrownae from Denmark mentioned in the scientific literature. The holotypes of Bln. kazimiroviensis, proposed by Jeletzky (1951) and Kongiel (1962), are also indicated (blank squares), in addition to the holotype of Bln. skolozdrownae from Denmark. The dashed lines indicate the variability of Bln. kazimiroviensis and BIn. skolozdrownae from the Middle Vistula valley (Poland) and the Maastricht area (the Netherlands, Belgium).

group of belemnites represents the presence of rather stout guards (Lsn $<45 \mathrm{~mm}$ ). These specimens, in part, resemble the original diagnosis of BIn. pensaensis (Naidin, 1952), for which a relatively small fissure angle, in addition to a comparatively stout guard, is typical (Naidin, 1952). However, the stout specimens are not characterised by smaller fissure angles in comparison with $B / n$. kazimiroviensis from western and central Europe (data not shown) and, hence, it cannot yet be decided whether Bln. pensaensis can be accepted as a separate, possibly southern Russian and/or Central Asian, (sub)species of the kazimiroviensis group or not. Until a detailed study will allow a final conclusion, specimens from central and southern Russia and Central Asia are best interpreted as Bln. kazimiroviensis in accordance to Naidin (1975), who mentioned that only a single species was present.

One specimen from southern Kazakhstan, illustrated by Jeletzky (1951, pl. 6, figure 1) is characterised by a rather lanceolate shape (AV c. 29\%) and a medium slender guard (Lsn c. $54 \mathrm{~mm}$ ) with a small fissure angle (FA c. $26^{\circ}$ ). A comparable specimen has not yet been found in central and western
Europe and may indicate the possibility that another species (or subspecies) of the kazimiroviensis group inhabited Central Asia.

Belemnites from Denmark and type specimens of the kazimiroviensis group. To date, merely five specimens from Denmark have been illustrated in the scientific literature (Jeletzky, 1951; Birkelund, 1957), but we are aware of several others in private collections (compare e.g., Rasmussen et al., 2011). Two of these, including the holotype, plot close to the range of BIn. skolozdrownae, whereas the three other plot in that of Bln. kazimiroviensis from central Europe (Figure 16).

The holotype of Bln. kazimiroviensis, as proposed by Kongiel (1962), is a fairly typical specimen of the species, whereas that of Jeletzky (1951) is extreme with respect to its shape and standardised length (Figure 16). The fissure angle, however, separates Jeletzky's holotype from BIn. skolozdrownae. The holotype of the latter form, as proposed by Kongiel (1962), from Denmark is more slender than the majority of specimens referred to this species. 


\section{SYSTEMATIC PALAEONTOLOGY}

Order BELEMNITIDA von Zittel, 1895

Suborder BELEMNOPEINA Jeletzky, 1965

Family BELEMNITELLIDAE Pavlow, 1914

Genus BELEMNELLA Nowak, 1913

Subgenus NEOBELEMNELLA Naidin, 1975

Belemnella (Neobelemnella) kazimiroviensis

(Skołozdrówna, 1932)

Figure 17

1932 Belemnitella kazimiroviensis Skołozdrówna, p. 117.

1951 Belemnella casimirovensis (Skolozdrówna) var. skolozdrównae; Jeletzky (pars), p. 119, pl. 6, figure 4, pl. 7, figure 4 (non pl. 7, figure 1).

1951 Belemnella casimirovensis (Skolozdrówna) var. archangelskyi; Jeletzky (pars), p. 119, pl. 6, figure 3.

1957 Belemnella casimirovensis archangelskyi Jeletzky, 1951; Birkelund, p. 52, pl. 6, figure 5ac.

1962 Belemnitella pensaensis Naidin, 1952; Kongiel, p. 32, pl. 1, figures 4-12, pl. 2, figures 1-6, pl. 3, figures 1-3.

1962 Belemnitella archangelskyi (Jeletzky, 1951); Kongiel, p. 33, pl. 2, figures 7-12, pl. 3, figures 4-6, 10-12, pl. 4, figures 1-3.

1962 Belemnitella kazimiroviensis Skołozdrówna, 1932; Kongiel (pars), p. 35, pl. 3, figures 7-9, pl. 4 , figures $4-12$, pl. 5 , figures $1-3,7-12$, pl. 6, figures 1-6 (non pl. 5, figures 4-6).

1962 Belemnitella skolozdrównae (Jeletzky, 1951); Kongiel (pars), p. 36, pl. 6, figures 10-12, pl. 7, figures 1-9 (non pl. 6, figures 7-9).

2012b Belemnella (Neobelemnella) gr. kazimiroviensis (Skołozdrówna, 1932); Jagt, p. 100, pl. 2, figures 4-6.

2012c Belemnella (Neobelemnella) ex gr. kazimiroviensis (Skołozdrówna, 1932); Jagt, p. 131, pl. 28, figures $B-C, I, L$.

Material. Three fragments (Mcd45/1, Mcd45/2, and Mcd52) from the white opoka exposed at Mięćmierz) and one specimen (Mcd37) from Kazimierz, from level "w" of Pożaryski (1938). 18 specimens from the level " $x$ " of Pożaryski, from the Kazimierz Opoka including two from Kazimierz (Mcd36, Mcd44/5), six from Bochotnica (Mcd35/1, $\operatorname{Mcd} 43 / 1, \operatorname{Mcd} 43 / 3, \operatorname{Mcd} 43 / 4, \operatorname{Mcd} 43 / 6$, and Mcd51/4) and eight from Nasiłów (Mcd42/1-42/5, Mcd50/9-50/12). Level "y" of Pożaryski (1938) yielded two specimens, one (Mcd41) from Bochotnica and another (Mcd48) from Nasiłów. New collection from the glauconitic sandstone, above the Kazimierz Opoka at Nasiłów (= level "z" of Pożaryski (1938) yielded as follows: 20 specimens from the glauconitic sandstone below the "phosphatic layer" (MWGUW ZI/69/02, 04-08, 31, 35, 66, $68,71-73,75-78,80,85,87) ; 25$ specimens and from the "phosphatic layer" (MWGUW ZI/69/13-14, 16-17, 20-21, 42-56, 58-59, 62, 64). The lower part of greenish sandy gaize at the base of the Siwak yielded eight specimens (MWGUW ZI/69/26, 37$38,40-41,88-90)$.

The stratigraphically oldest specimens studied from the Netherlands (NHMM JJ 8338-JJ 8339) are from subunit IVf-4 of the Meerssen Member at the former Blom quarry, followed by a specimen from either subunit IVf-4 or -5 from the ENCl-HeidelbergCement Group quarry (NHMM JJ 8758). Specimen NHMM JJ 2440 stems from either subunit IVf-5 or -6 as formerly exposed at the Albert Canal near Vroenhoven. Three specimens are known from subunit IVf-6: from the former Blom quarry (base IVf-6; NHMM 2015 NK001-11), from the uppermost Meerssen Member as exposed at the ENCl-Heidelberg Cement Group quarry (probably IVf-6; NHMM MK4594) and from the former Curfs quarry (top IVf-6 - 0.5 m; NHMM JJ 7175). From immediately above the Berg en Terblijt Horizon (K-Pg boundary) 14 specimens have been studied from the Geulhemmergroeve subterranean galleries near Geulhem (NHMM MK 2505-2508, MK 2514-2519, MK 2522, NHMM 2015 NK001-2, NHMM 2015 NK001-3, and NHMM 2015 NK0014), in addition to one specimen from the former Blom quarry (NHMM MK 2723). The lowermost $0.05 \mathrm{~m}$ above the Vroenhoven Horizon (lowermost Geulhem Member, Houthem Formation) have yielded 12 specimens (NHMM 2015 NK001-13, NHMM 2015 NK001-14, NHMM 2015 NK001-15, NHMM 2015 NK001-17, NHMM 2015 NK001-20, NHMM 2015 NK001-21, NHMM 2015 NK001-22, NHMM 2015 NK001-23, NHMM 2015 NK001-26, NHMM 2015 NK001-28, NHMM 2015 NK001-32, and NHMM 2015 NK001-37) at the Albert Canal near Vroenhoven and three specimens (NHMM JJ 14048-1, JJ 14048-6, JJ 14048-7) in the former Curfs-Ankerpoort quarry.

Description. Guard shape in Bln. kazimiroviensis varies from subcylindrical to slightly lanceolate in ventral view. In lateral view, guards are subconical to subcylindrical. Guard length (Ls) usually is small to large, but extraordinarily large guards may rarely occur, indicating that the populations from the Middle Vistula valley and Maastricht area consists mainly of specimens that have not reached their physiologically possible maximum size. The standardised length (Lsn) varies from c. 42 to $64 \mathrm{~mm}$. Schatzky distances are relatively small (1.0-4.7 


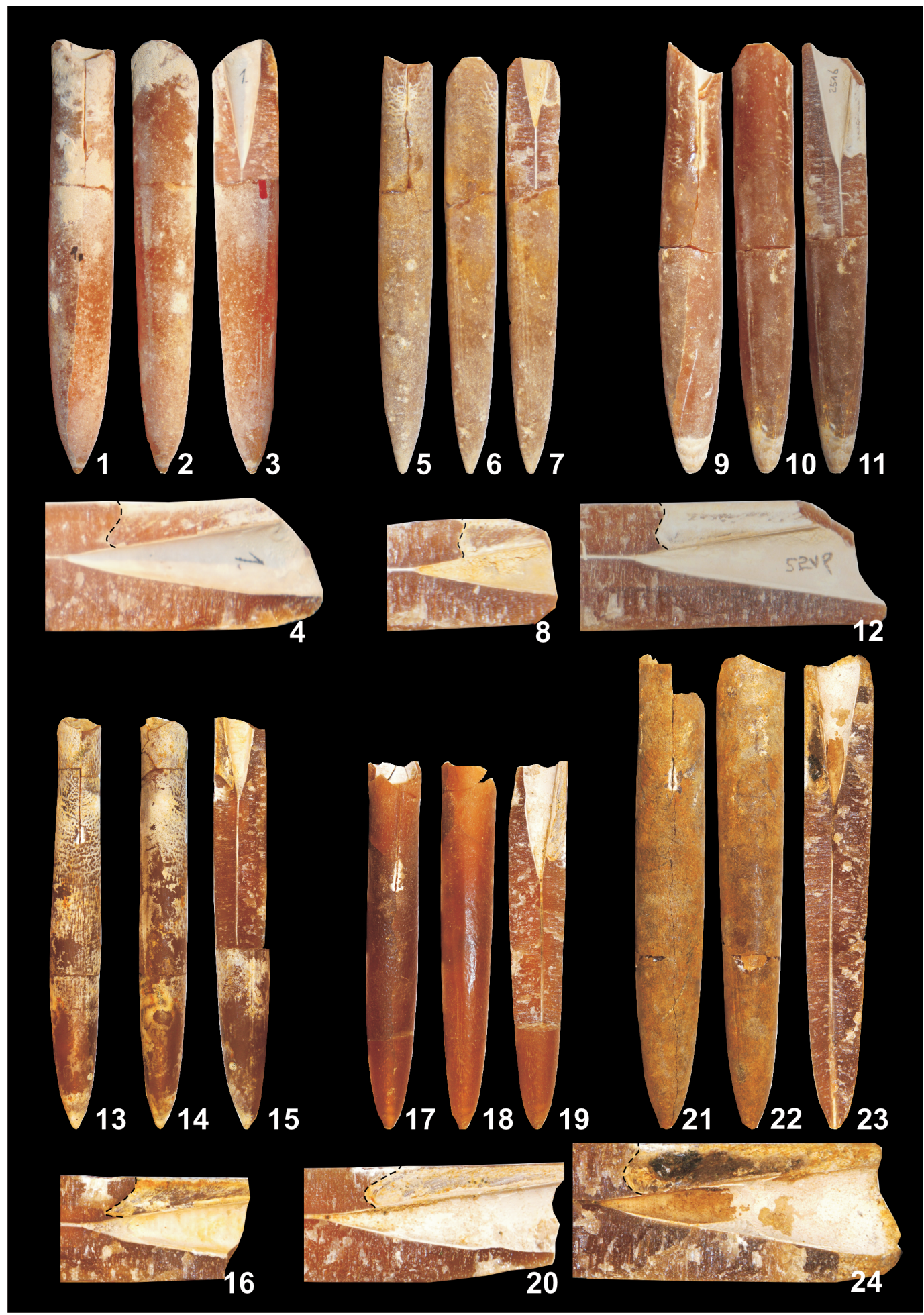

FIGURE 17. Belemnella (Neobelemnella) kazimiroviensis (Skołozdrówna, 1932). 1-4, NHMM JJ 4048/1, former Curfs-Ankerpoort quarry; basal Geulhem Member, Vroenhoven Horizon, + 0.00-0.05 m; 5-8, NHMM JJ 8339, former Blom quarry, Meerssen Member IVf-4; 9-12, NHMM MK 2516, Geulhemmerberg subterranean galleries near Geulhem, top of Meerssen Member (IVf-6); 13-16, MWGUW ZI/69/44, 17-20, ZI/69/47 and 21-24, ZI/69/51, respectively, from the "phosphatic layer" at Nasiłów quarry. All specimens are in natural size in following views: dorsal $(\mathbf{1 , 5 , 9 , 1 3 ,}$ $17,21)$, lateral $(2,6,10,14,18,22)$, longitudinally split specimen showing internal features $(3,7,11,15,19,23)$, and close-up of alveolar part [x2] with the course of the bottom of ventral fissure - dashed line $(4,8,12,16,20,24)$. 
$\mathrm{mm}$ ) with population mean values around $3.4 \mathrm{~mm}$. The alveolar angle ranges from $16^{\circ}$ to $21^{\circ}$. The fissure angle is highly variable and ranges from $24^{\circ}$ to $138^{\circ}$ (mean value c. $73^{\circ}$ ). In well-preserved guards the vascular markings and double furrows are well developed. Longitudinal striae crossing the vascular markings result in a kind of pseudogranulation that is most distinct in the anterior part of the guard. The apical end may be acute to roundedacute; only in larger specimens is it more rounded. A distinct mucro is rarely visible. The ontogenetic growth quotient of individual guards (WQs) was calculated on four specimens (MWGUW ZI/69/07, 16, 59, and NHMM 2015 NK001-14); the mean value being 3.73 .

The relationship $\mathrm{BI}$ vs Dp (Figure 18) of guards of Bln. kazimiroviensis is not linear as in the genus Belemnitella d'Orbigny, 1840. Instead, small (young) individuals are distinctly more slender than larger (adult) ones. This allometric growth is, in addition to other aspects, considered typical of the genus Belemnella.

From the regression equation (Figure 18), BI $\mathrm{x}$-values for $\mathrm{Dp} 1=5 \mathrm{~mm}$ and $\mathrm{Dp} 2=16 \mathrm{~mm}$ were calculated. The corresponding BI1- and BI2-values were used to calculate Ls1 and Ls2, from which the "alternative WQs" could be deduced. In this way, based on a large population, the calculated "alternative WQs" accounts for 3.33 and is distinctly smaller than the mean value of the ontogenetic growth quotient of individual guards (WQs = 3.73) calculated from merely four specimens. The Lsn values of Bln. kazimiroviensis are best calculated as follows:

Lsn = Dpn $\times$ BIn = $9.9 \times(5.28+(B I-(-1.932 \ln (D p)+9.7097)))$ (in $\mathrm{mm}$ )

Although the majority of specimens of Bln. kazimiroviensis from the Maastricht area plot well within the range of this species from the Middle Vistula valley region, the mean values of $\mathrm{AV}$ and $\mathrm{AL}$ indicate that the Maastricht specimens are slightly more subcylindrical in ventral and more subconical in lateral view (Table 4). The significance of this observation is not yet clear. It might indicate a developmental trend, since the population from the Maastricht area represents the stratigraphically youngest population studied, but it may also simply reflect a local phenomenon of the Maastricht population that established itself on the western margin of distribution of Bln. kazimiroviensis.

Discussion. Belemnella kazimiroviensis represents the type species of the kazimiroviensis group. However, many varieties of this species have been distinguished. Jeletzky (1951) was the first who formally introduced Bln. kazimiroviensis, making reference to "Belemnitella kazimiroviensis" of Skołozdrówna (1932). Unfortunately, he misspelt the name as "casimirovensis". Jeletzky examined the Skołozdrówna Collection at L'viv (Ukraine), and received a few specimens from this lot. From these he selected one as the holotype of Bln. kazimiroviensis. Presumably Jeletzky had already recognised the presence of two species of Belemnella in the uppermost Maastrichtian of the Middle Vistula valley in Poland, which allowed him to differentiate between two varieties, "Belemnella casimirovensis (Skolozdrówna) var. skolozdrównae" and "Belemnella casimirovensis (Skolozdrówna) var. archangelskyi". He intended to have the name of the first species to refer to the more slender, lanceolate variety characterised by larger fissure angles, which is generally rare, but seemingly more common in the central Vistula valley than elsewhere. The present results seem to imply that what Jeletzky (1951) had in mind is what is here referred to as Bln. skolozdrownae (Kongiel, 1962). However, the present study also revealed that the fissure angle of Jeletzky's holotype of "Belemnella casimirovensis (Skolozdrówna) var. skolozdrównae" is relatively small, characterising it as a slender representative of the "var. archangelskyi" sensu Jeletzky (1951).

Jeletzky (1951) clearly stated that the holotype of the variety "Belemnella casimirovensis (Skolozdrówna) var. skolozdrównae" was also the holotype of "Belemnella casimirovensis (Skolozdrówna)". As a consequence, the variety skolozdrównae of Jeletzky (1951) is invalid. Instead, the holotype of Jeletzky should be referred to as Bln. kazimiroviensis kazimiroviensis if a subspecies would need to be distinguished, as proposed earlier by Birkelund (1957).

With respect to the "var. archangelskyi" of Jeletzky (1951), it may be concluded that, following his concept, this variety must be regarded as a synonym of Bln. kazimiroviensis kazimiroviensis, because the holotype of the latter species is not a member of the second, more slender and more lanceolate form (i.e., Bln. skolozdrownae) that occurs in the Middle Vistula valley. However, since the holotype of "Belemnella casimirovensis (Skolozdrówna) var. archangelskyi" is a specimen from the Turgay Plateau (northwest Kazakhstan), as illustrated by Arkhangelsky (1912) under the designation "Belemnitella americana", it cannot be ruled out that this represents indeed a valid geo- 


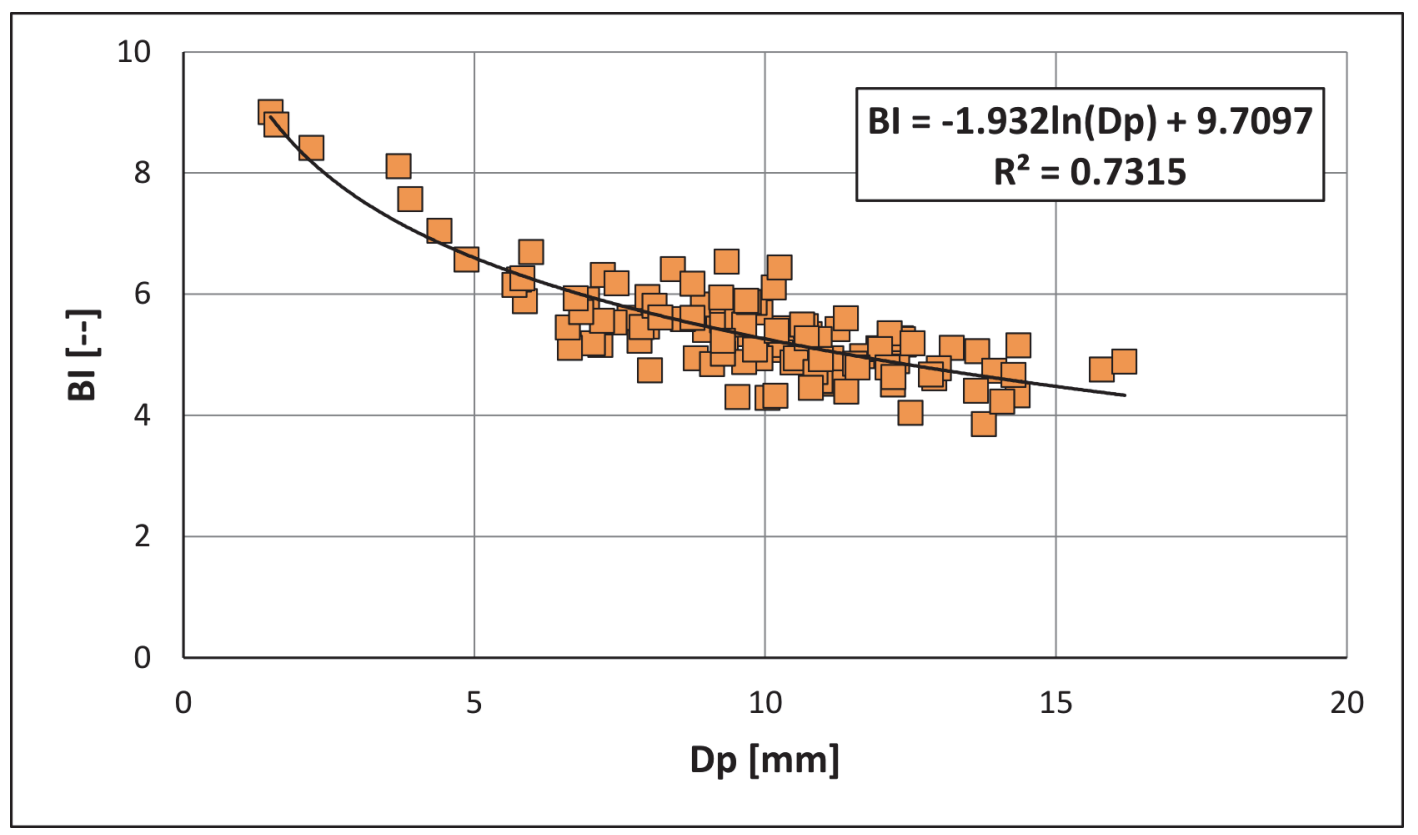

FIGURE 18. Relationship of $\mathrm{BI}$ (Birkelund Index) vs Dp (dorso ventral diameter at the protoconch) $(\mathrm{BI}=\mathrm{Ls} / \mathrm{Dp}$; compare with Figure 6) of guards of Bln. kazimiroviensis from the Middle Vistula valley and the Maastricht area. The growth relationship is best described by a logarithmic curve.

graphical (sub)species of Bln. gr. kazimiroviensis. This shall be the subject of future studies.

Naidin (1952) listed two varieties of "Belemnitella arkhangelskii nomen novum", namely "Belemnitella arkhangelskii nomen novum var. pontica (Rousseau)" and "Belemnitella arkhangelskii nomen novum var. pensaensis var. nov." While, for the time being, the holotype of Belemnites ponticus is best regarded as a nomen dubium (Kongiel, 1962), that of BIn. pensaensis deserves further discussion. According to the original description (Naidin, 1952), the holotype of Bln. pensaensis from Nikiforowka near Penza (central Russia) was comparatively stout and characterised by a relatively small fissure angle. Jeletzky (1958) accepted the validity of the Bln. pensaensis and argued that representatives of the kazimiroviensis group from central Russia might differ slightly from those recorded from southern Russia and Central Asia (i.e., the origin of the holotype of Bln. arkhangelskii) as well as from those of Poland (i.e., origin of the holotype of BIn. kazimiroviensis), implying that BIn. arkhangelskii and/or Bln. pensaensis might represent valid geographical (sub)species of the kazimiroviensis group.

Kongiel (1962) erected an additional species of the kazimiroviensis group, viz. Bln. skolozdrownae. He argued that the holotype of "Belemnella casimirovensis (Skolozdrówna) var. skolozdrównae", as selected by Jeletzky (1951), with respect to its fissure angle, did not reflect the course of the ventral fissure as described by Skołozdrówna for "Belemnitella kazimiroviensis". Consequently, he selected another holotype for Bln. skolozdrownae from one of the paratypes of Jeletzky (1951, pl. 7, figure 1) - the specimen from Stevns Klint (Denmark). Because the designation "var. skolozdrównae" was incorrectly introduced by Jeletzky (1951), the holotype introduced by Kongiel is considered valid. The holotype of Bln. skolozdrownae sensu Kongiel (1962) differs from BIn. kazimiroviensis in its more slender guard, more lanceolate shape, and larger fissure angle. In addition, it reflects well the concept of "Belemnella casimirovensis (Skolozdrówna) var. skolozdrównae" of Jeletzky (1951) and is here accepted as the holotype of the second species that is rare in central and western Europe.

Distribution. With respect to the locus typicus and stratum typicum of Bln. kazimiroviensis Jeletzky (1951, p. 122) mentioned "...Locus typicus: Umgebung der Stadt Kazimierz an der Weichsel in Polen. Stratum typicum: Oberste Horizonte der Maastricht-Stufe (Horizonte "w", "x", "y" (nicht "z"!) von Pożaryski (1938, S. 18-19)..." This actually restricts the origin of the holotype of Bln. kazimiroviensis to the Kazimierz Opoka and excludes the glauconitic sandstone at its top, although it may 
TABLE 4. Comparison of characteristic parameters of Bln. kazimiroviensis from the Nasiłów area (the Middle Vistula valley, Poland), the Maastricht area (the Netherlands, Belgium) and central and southern Russia as well as Central Asia (for abbreviations see the section Morphometrics of Material and Methods). Data represent means \pm standard deviation. Different letters ( $a$ or $b$ ) within a row indicate significant differences by Tukey HSD test for unequal number of specimens (ANOVA) or Mann-Whitney $U$ test in case the variances were even after data transformation not homogeneously distributed. In the latter case the significance level was corrected according to Bonferroni.

\begin{tabular}{lccccc}
\hline & $\begin{array}{c}\text { Nasiłów area - } \\
\text { Kazimierz Opoka }\end{array}$ & $\begin{array}{c}\text { Nasiłów area - } \\
\text { glauconitic } \\
\text { sandstone }\end{array}$ & $\begin{array}{c}\text { Nasiłów area - } \\
\text { basal Siwak }\end{array}$ & Maastricht area & $\begin{array}{c}\text { Central and } \\
\text { southern Russia; } \\
\text { Central Asia }\end{array}$ \\
\hline Ls [mm] & $57.2 \pm 8.2 \mathrm{a}$ & $52.6 \pm 8.8 \mathrm{a}$ & $47.1 \pm 8.5 \mathrm{a}$ & $50.9 \pm 10.6 \mathrm{a}$ & $53.3 \pm 17.2 \mathrm{a}$ \\
$\mathrm{Dp}[\mathrm{mm}]$ & $11.0 \pm 2.3 \mathrm{a}$ & $10.4 \pm 2.2 \mathrm{a}$ & $9.3 \pm 2.5 \mathrm{a}$ & $9.5 \pm 2.3 \mathrm{a}$ & $10.7 \pm 3.5 \mathrm{a}$ \\
$\mathrm{SW}[\mathrm{mm}]$ & $3.3 \pm 0.6 \mathrm{a}$ & $3.4 \pm 0.8 \mathrm{a}$ & $3.8 \pm 0.9 \mathrm{a}$ & $3.5 \pm 0.7 \mathrm{a}$ & $3.2 \pm 0.7 \mathrm{a}$ \\
$\mathrm{AA}\left[^{\circ}\right]$ & $18.5 \pm 1.1 \mathrm{ab}$ & $18.5 \pm 1.3 \mathrm{ab}$ & $20.0 \pm 0.7 \mathrm{a}$ & $18.8 \pm 1.4 \mathrm{ab}$ & $18.0 \pm 1.8 \mathrm{~b}$ \\
$\mathrm{FA}\left[{ }^{\circ}\right]$ & $73.4 \pm 25.3 \mathrm{a}$ & $73.2 \pm 27.2 \mathrm{a}$ & $59.8 \pm 28.9 \mathrm{a}$ & $72.9 \pm 27.4 \mathrm{a}$ & $63.0 \pm 31.5 \mathrm{a}$ \\
$\mathrm{BI}[--]$ & $5.3 \pm 0.5 \mathrm{a}$ & $5.2 \pm 0.6 \mathrm{a}$ & $5.1 \pm 0.5 \mathrm{a}$ & $5.4 \pm 0.6 \mathrm{a}$ & $5.0 \pm 0.6 \mathrm{a}$ \\
$\mathrm{Lsn}[\mathrm{mm}]$ & $54.0 \pm 2.8 \mathrm{a}$ & $51.5 \pm 4.6 \mathrm{a}$ & $49.3 \pm 3.2 \mathrm{a}$ & $52.3 \pm 5.0 \mathrm{a}$ & $50.1 \pm 7.9 \mathrm{a}$ \\
$\mathrm{AV}[\%]$ & $12.1 \pm 5.8 \mathrm{ab}$ & $11.1 \pm 7.0 \mathrm{a}$ & $9.6 \pm 7.6 \mathrm{ab}$ & $6.7 \pm 5.4 \mathrm{~b}$ & $13.9 \pm 6.0 \mathrm{a}$ \\
$\mathrm{AL}[\%]$ & $-4.2 \pm 4.4 \mathrm{a}$ & $-5.9 \pm 6.5 \mathrm{a}$ & $-5.0 \pm 5.4 \mathrm{a}$ & $-10.2 \pm 5.4 \mathrm{a}$ & $-3.3 \pm 9.2 \mathrm{a}$ \\
$\mathrm{AVs}[\%]$ & $7.4 \pm 4.8 \mathrm{ab}$ & $6.4 \pm 6.1 \mathrm{ab}$ & $5.8 \pm 6.0 \mathrm{ab}$ & $3.1 \pm 4.8 \mathrm{~b}$ & $9.7 \pm 5.7 \mathrm{a}$ \\
$\mathrm{ALs}[\%]$ & $-5.0 \pm 4.0 \mathrm{a}$ & $-6.2 \pm 5.2 \mathrm{a}$ & $-6.4 \pm 4.2 \mathrm{a}$ & $-9.6 \pm 3.9 \mathrm{a}$ & $-3.6 \pm 6.6 \mathrm{a}$ \\
\hline
\end{tabular}

be questioned whether the holotype did indeed come from the opoka, since Jeletzky did not collect it by himself. In view of the fact that Jeletzky refused the glauconitic sandstone as a stratum typicum, we are left here essentially with the upper part of the upper Maastrichtian Kazimierz Opoka as exposed at Nasiłów, Bochotnica, and at the Town Quarry at Kazimierz Dolny (the latter with numerous belemnites only in the marls at the top of the exposure) as a potential stratum typicum for Bln. kazimiroviensis. All these levels correspond to the late but not latest Maastrichtian $H$. constrictus crassus Zone.

Belemnella kazimiroviensis occurs in the upper upper Maastrichtian of the Middle Vistula valley in Poland, at several localities in Denmark and in the uppermost Maastrichtian of the Maastricht area (the Netherlands, Belgium). The late Maastrichtian specimens of Bln. kazimiroviensis illustrated by Naidin (1975) from central and southern Russia and Central Asia are characterised by mean values for characteristic parameters that do not differ from those of the populations from the Middle Vistula valley (Table 4) and may, thus, also be referred to as BIn. kazimiroviensis, unless future studies will prove the existence of geographical (sub)species in these areas.
Belemnella (Neobelemnella) skolozdrownae (Kongiel, 1962)

Figure 19

1951 Belemnella casimirovensis (Skolozdrówna) var. skolozdrównae; Jeletzky (pars), p. 119, pl. 7, figure 1 (non pl. 6 figure 4, pl. 7, figure 4).

1957 Belemnella casimirovensis casimirovensis (Skolozdrówna, 1932), 1951; Birkelund, p. 50, pl. 6, figure 4a-c.

1962 Belemnitella kazimiroviensis Skołozdrówna, 1932; Kongiel (pars), p. 35, pl. 5, figures 4-6 (non pl. 3 , figures $7-9$, pl. 4 , figures $4-12$, pl. 5, figures 1 $3,7-12$, pl. 6, figures 1-6).

1962 Belemnitella skolozdrównae (Jeletzky, 1951); Kongiel, p. 36, pl. 6, figures 7-9 (non pl. 6, figures $10-12$, pl. 7, figures 1-9).

Material. Two specimens (Mcd43/2, Mcd50/7) from level "x" sensu Pożaryski (1938) of the Kazimierz Opoka from Bochotnica and Nasiłów, respectively, in the Middle Vistula valley in Poland. 13 recently collected specimens from the Nasiłów quarry (MWGUW ZI/69/01, 03, 65, 67, 69-70, 74, $79,81-84$, and 86 ) from the glauconitic sandstone below the "phosphatic layer" and six specimens (MWGUW ZI/69/15, 18, 57, 60-61, 63) from the "phosphatic layer". One specimen (Ma21= NHMM JJ 8759) from subunit IVf-4 or IVf-5 of the Meerssen Member at the ENCl-HeidelbergCement Group quarry, one specimen (Ma4 = NHMM MK 2815) from the uppermost Meerssen Member of 


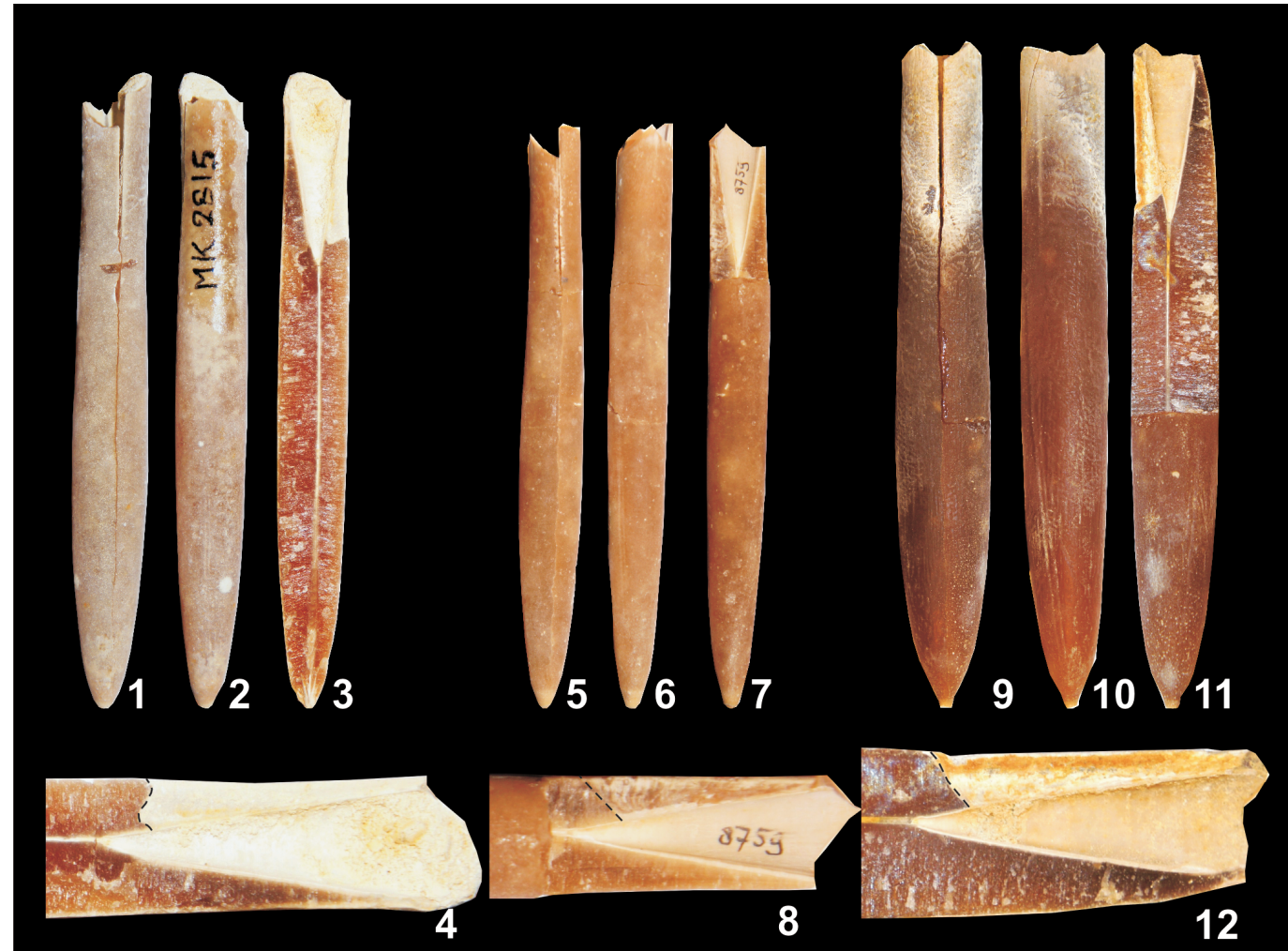

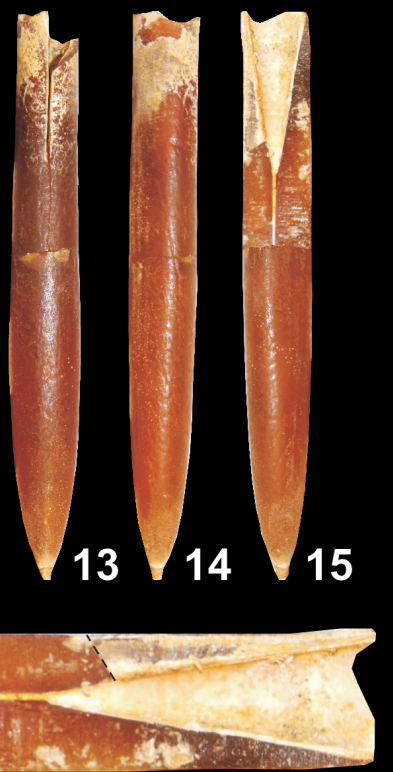

16
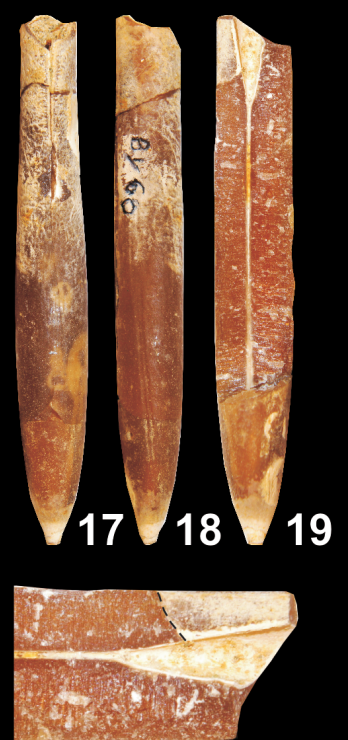

20
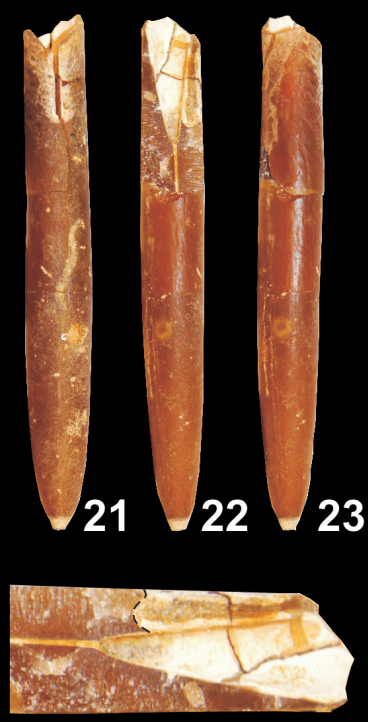

24

FIGURE 19. Belemnella (Neobelemnella) skolozdrownae (Kongiel 1962). 1-4, NHMM MK 2815, Albert Canal near Vroenhoven (61F-19), uppermost Meerssen Member; 5-8, NHMM JJ 8759, ENCI-HeidelbergCement Group quarry, Maastricht, Meerssen Member, IVf-4 or IVf-5; 9-12, MWGUW Zl/69/70, and 13-16, Zl/69/86 - from the glauconitic sandstone below the "phosphatic layer" at Nasiłów; 17-20, MWGUW Zl/69/60 and 21-24, Zl/69/61 - from the "phosphatic layer" at Nasiłów quarry. All specimens are in natural size in following views: dorsal $(\mathbf{1}, \mathbf{5}, \mathbf{9}, 13,17,21)$, lateral $(2,6,10,14,18,22)$, longitudinally split specimen showing internal features $(3,7,11,15,19,23)$, and close-up of alveolar part [x2] with the course of the bottom of ventral fissure - dashed line $(4,8,12,16,20,24)$. 
TABLE 5. Mean values and standard deviation (SD) of critical characters of Bln. skolozdrownae from the Middle Vistula valley region and the Maastricht area (for abbreviations see the section Morphometrics of Material and Methods). Extreme values of a probably pathological specimen from Maastricht (NHMM 2015 NK001-18) are given in brackets and are not included in the calculation of the means.

\begin{tabular}{lcc}
\hline & Means \pm SD & Observed range \\
\hline Ls [mm] & $56.9 \pm 7.6$ & $49.0-81.0$ \\
Dp [mm] & $8.9 \pm 1.6$ & $5.4-13.5$ \\
SW [mm] & $3.1 \pm 0.7$ & $2.0-5.0$ \\
AA [ $\left.{ }^{\circ}\right]$ & $18.8 \pm 1.5$ & $16-21$ \\
FA [ $\left.{ }^{\circ}\right]$ & $107.2 \pm 20.3$ & $70-138$ \\
BI [--] & $6.4 \pm 0.5$ & $5.7-7.6(9.3)$ \\
Lsn [mm] & $61.2 \pm 4.1$ & $54.0-70.5(79.9)$ \\
AV [\%] & $22.9 \pm 7.6$ & $11.6-35.4$ \\
AL[\%] & $4.7 \pm 5.2$ & $-3.6-15.5(30.8)$ \\
AVs [\%] & $15.5 \pm 5.8$ & $6.6-30.2$ \\
ALs [\%] & $0.7 \pm 3.5$ & $-4.9-8.4(22.9)$ \\
\hline
\end{tabular}

locality 61F-19 at the Albert Canal, and one (NHMM 2015 NK001-18) from immediately above the Vroenhoven Horizon at the Albert Canal near Vroenhoven.

Description. Specimens here referred to Bln. skolozdrownae are characterised by large fissure angles (FA $>70^{\circ}$ ), a slightly (occasionally distinctly) lanceolate shape in ventral (AV usually > $20 \%$ ), and (usually) subcylindrical shape in lateral view (AL > $-4 \%$ ), in addition to a relatively slender guard (Lsn usually > $55 \mathrm{~mm}$ ). Schatzky distances and alveolar angles are not different from representatives of Bln. kazimiroviensis (Tables 4 and 5). Vascular markings and dorsolateral double furrows are well developed in well-preserved specimens. Longitudinal striae may be present and can result, in combination with the vascular markings, in a kind of pseudogranulation, especially in the anterior part of the guards. The apical end is frequently relatively acute, but may also be rounded with a less distinct mucro. The ontogenetic growth quotient of individual guards (WQs) could be calculated in a single specimen (MWGUW ZI/69/63) and accounted for 5.64 .

Due to the limited number of specimens available of Bln. skolozdrownae, both guards illustrated by Jeletzky (1951) and Birkelund (1957) were added for the study of the relationship $\mathrm{BI} v s$. Dp (Figure 20). From the regression equation the "alternative WQs" for the interval between Dp1 $=5$ $\mathrm{mm}$ and Dp2 $=14 \mathrm{~mm}$ was calculated. The corresponding value accounted for 4.47 , i.e., distinctly larger than that of Bln. kazimiroviensis (3.33). The Lsn values of Bln. skolozdrownae can be calculated as follows:
Lsn $=$ Dpn $\times$ BIn $=9.9 \times(6.30+(B I-(-1.997 \ln (D p)+10.879)))$ (in $\mathrm{mm}$ )

Discussion. Jeletzky (1951) recorded that the holotype of Bln. skolozdrownae was found c. $20 \mathrm{~m}$ below the K-Pg boundary at Stevns Klint. Thus, it is from the upper Sigerslev Member and stems from the zone with $H$. constrictus crassus. In consequence, the holotype of Bln. skolozdrownae is older than the material from Maastricht and stratigraphically related to specimens from the Kazimierz Opoka in the central Vistula River valley.

Distribution. Belemnella skolozdrownae is recorded from the upper upper Maastrichtian Sigerslev Member in Denmark (upper part of the zone with $H$. constrictus crassus) and from about the same level in Poland (Kazimierz Opoka). In the Maastricht area it ranges into the upper Meerssen Member up to the end of the Maastrichtian Stage (IVf-4 to IVf-6), including the zone with $H$. constrictus johnjagti.

\section{INTERPRETATIONS AND CONCLUSIONS}

In central Europe, the earliest, well-documented typical specimens of Bln. kazimiroviensis originate from Męćmierz, Poland (Kazimierz Opoka), from within the Hoploscaphites constrictus crassus Zone of Machalski (2005b) and foraminifera Assemblage Zone $X$ of Dubicka and Peryt (2012) (for zonation overview see Walaszczyk et al., 2016).

In the Kazimierz Opoka of the Middle Vistula River valley, Bln. kazimiroviensis is the dominant species. Additionally, from the upper 14 metres of that unit (i.e., level "x" sensu Pożaryski, 1938), two 


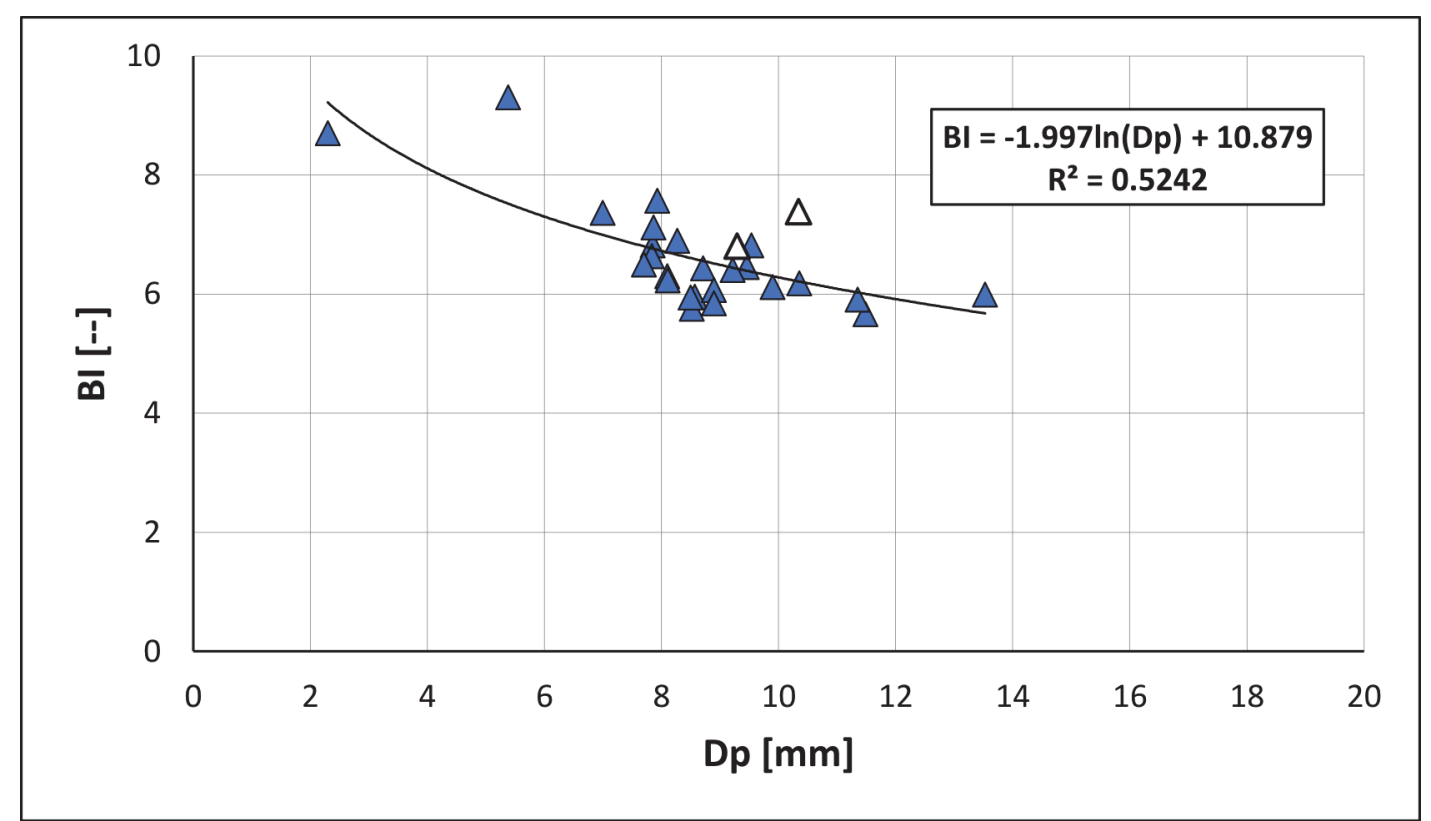

FIGURE 20. Relationship of BI (Birkelund Index) vs Dp (dorso ventral diameter at the protoconch) (BI = Ls/Dp; compare with Figure 6) of guards of Bln. skolozdrownae from the Middle Vistula valley in Poland and the Maastricht area in the Dutch-Belgian border region, in addition to two specimens from Denmark (blank triangles) as illustrated in the scientific literature (Jeletzky, 1951, pl. 7, figure 1; Birkelund, 1957, pl. 6, figure 4).

specimens of Bln. skolozdrownae have been identified at Bochotnica and Nasiłów, where they cooccur with the index ammonite $H$. constrictus crassus. In Denmark Bln. kazimiroviensis and Bln. skolozdrownae also co-occur with that ammonite chronosubspecies in what is now referred to as the upper Sigerslev Member (Jeletzky, 1951).

The stratigraphically oldest, late Maastrichtian representatives of the genus Belemnella in the Maastricht area have been recorded from the top of subunit IVf-3 or the base of IVf-4 of the Meerssen Member (Jagt, 2012b). Belemnella is rare in these biocalcarenites and usually is found directly on top of hardgrounds or within the overlying fossil hash layers. Most of the guards studied from this area originate from directly above the Berg en Terblijt Horizon (= K-Pg boundary) or from the base of the overlying early-middle Danian Geulhem Member (i.e., directly above the Vroenhoven Horizon). Two species are present, Bln. kazimiroviensis (frequent) and Bln. skolozdrownae (rare).

The identification of the stratigraphically youngest belemnite fauna in Poland has turned out to be fraught with difficulties. In part this is due to the fact that unequivocally uppermost Maastrichtian deposits are rarely exposed. From Mełgiew, Machalski (2005a, 2005b) recorded $H$. constrictus johnjagti Machalski, 2005 from an interval below the K-Pg boundary that was at least $3 \mathrm{~m}$ thick. To date, this trench represents the sole locality at which the youngest portion of the Maastrichtian Stage has been documented on the basis of the index ammonite subspecies. However, belemnites were not found (M. Machalski, personal commun., 2015). The uppermost Maastrichtian was also accessible at Lechówka near Chełm, where a complete shallow-marine succession across the K-Pg boundary was exposed. Again, ammonites were recovered, but no belemnites (Racki et al., 2011; Machalski et al., 2016).

Contrary to Mełgiew and Lechówka, belemnites are common in the glauconitic sandstone that rests on top of the Kazimierz Opoka at Nasiłów. This "greensand" is here interpreted as being of Danian age and contains reworked belemnites of late Maastrichtian age. Due to the redeposited character of the deposit and the lack of belemnites from Mełgiew and Lechówka, it remains a matter debate, whether the belemnite assemblage from the glauconitic sandstone contains also belemnites of latest Maastrichtian age $(H$. constrictus johnjagti Zone).

With respect to the depositional history at Nasiłów, it may be deduced that all of the belemnites from the glauconitic sandstone are allochthonous. In this context the excellently preserved specimen with a proostracum found in the glauconitic sandstone (Figure 21) is worth mentioning, 


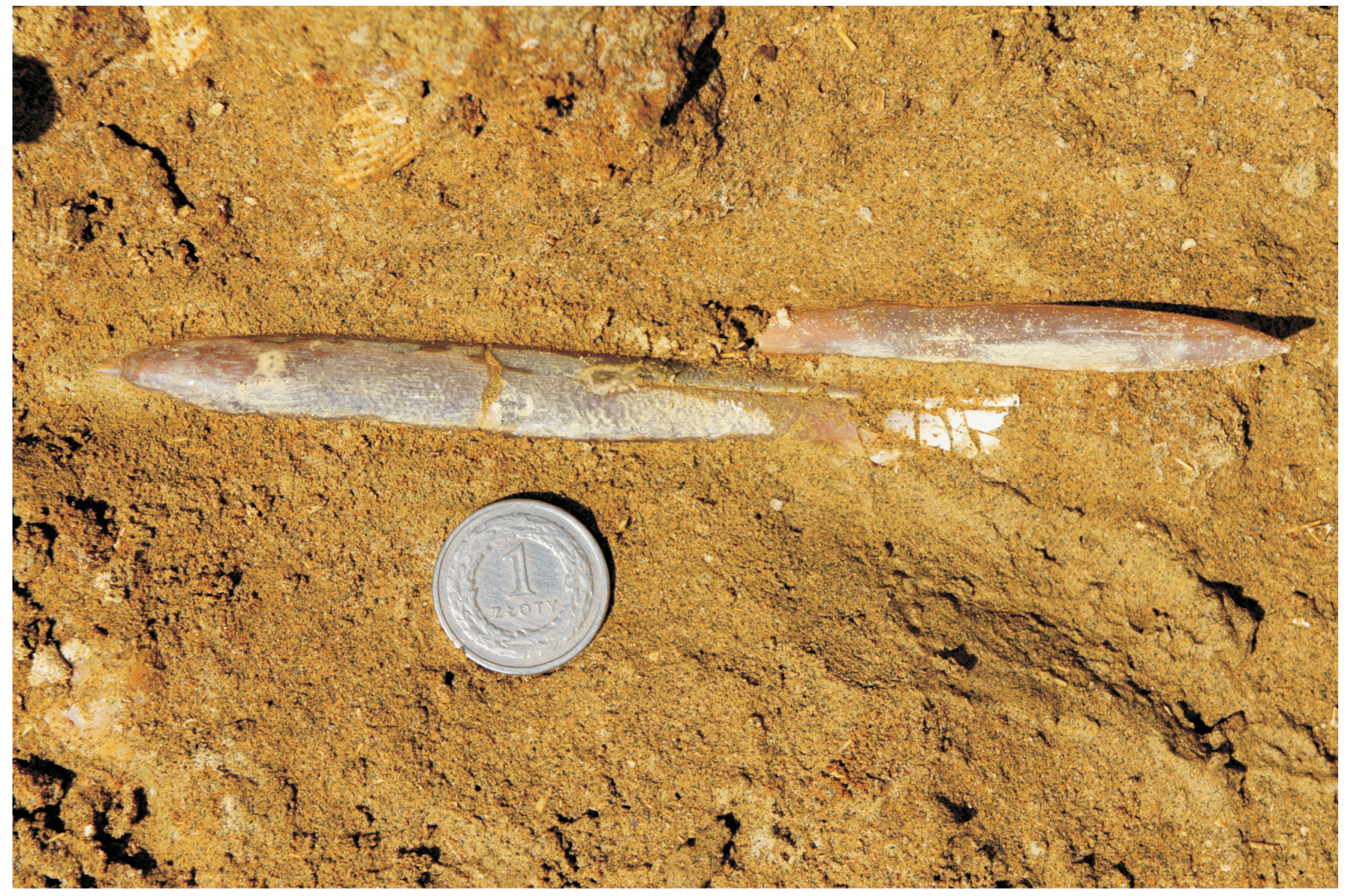

FIGURE 21. An excellently preserved specimen of Bln. kazimiroviensis (left) retaining part of the proostracum, together with a normally preserved guard (right) in the glauconitic sandstone at Nasiłów (field photograph; specimen with proostracum could not be collected completely).

because, obviously, it did not experience any longlasting reworking processes or strong current action. Its preservation is best explained by delicate winnowing.

\section{Palaeobiological interpretation of belemnites from Nasiłów and Maastricht}

The present study revealed an unusually large number of relatively small belemnite specimens at Nasiłów and Maastricht. On one hand, such an occurrence of small specimens is highly unusual; such has not been observed previously by us. On the other hand, reliable data on size distribution of belemnites suitable for comparison are limited. We assume that the observed distribution of size groups reflects a typical population for the shallowmarine ecosystems that persisted around Nasiłów and Maastricht at the end of the Maastrichtian Stage. The decreased number of representatives with a dorsoventral diameter of $>6 \mathrm{~mm}$ is a reflection of natural processes such as the removal of larger-sized individuals from populations by predator action, disease, accident, or migration into other, possibly deeper, habitats.
These data were used to estimate the percentage of specimens that remained in the ecosystem per annum. Firstly, we assumed that Bln. gr. kazimiroviensis attained a maximum age of c. 5 years (Schmid, 1960), which is close to that of modern large squid. Secondly, we interpreted the increase of the dorsoventral diameter to have been near stable during the life cycle of Bln. gr. kazimiroviensis. In view of the fact that the largest specimens from both Nasiłów and Maastricht are in the size group "16 to $18 \mathrm{~mm}$ " (compare Figure 18), this was equated with an age of five years; the remaining size groups were transformed to mean ages. The sum of all specimens was equal to $100 \%$ and the number of specimens per size group(s) was subtracted in order to calculate the percentage of remaining specimens. Of note is that the following considerations do not depend of the assumed maximum age of five years. Similar conclusions could be deduced for a maximum age of c. 1 year, which would be typical of most extant cephalopods.

The percentage of specimens per age-group is best described by an S-shaped curve, while a 


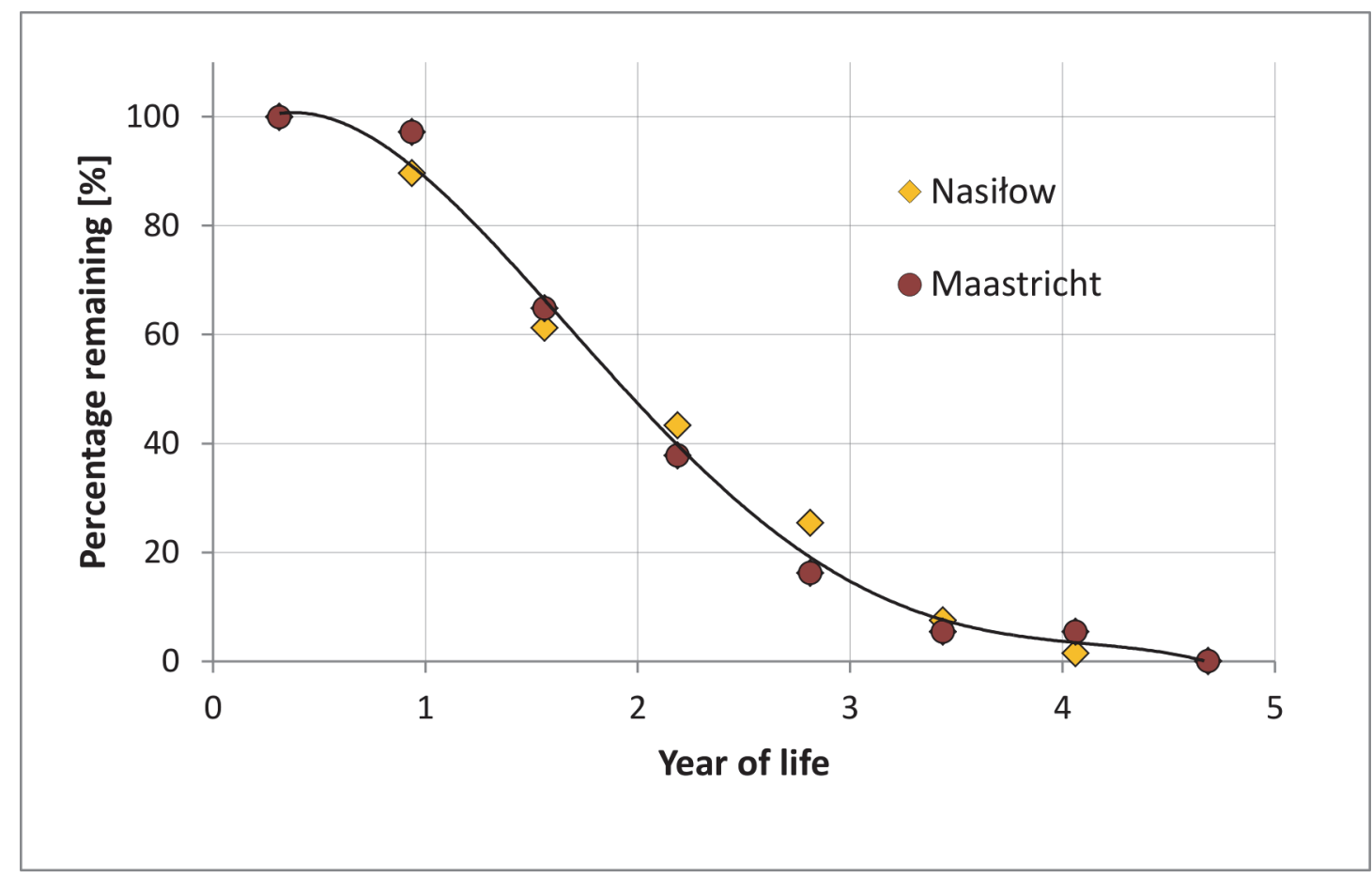

FIGURE 22. Estimation of percentage of belemnites of the kazimiroviensis group remaining in the habitat, calculated from size-group distribution at Nasiłów (Poland) and the Maastricht area (the Netherlands, Belgium).

linear approximation is less suitable (Figure 22). The shape of the curve implies that smaller individuals had a better chance to survive, possibly because they could more easily hide in shallowmarine habitats among sponges, sea grasses, bryozoan thickets, and coral colonies. However, it is also possible that they lived in another ecosystem (infralittoral zone?) and, hence, appeared less frequently in the fossil record. In addition, it should be considered that the fossilisation potential of very small individuals of Belemnella could have been limited, altogether resulting in an overestimation of individuals that remained in the ecosystem.

During the second and third year of their lives, the belemnites suffered their largest losses from the habitats considered (Figure 22), either due to dieback or migration into other, possibly deeper, settings. Based on this observation, it may be hypothesised that the majority of specimens reached maturity after $c$. 2-3 years and died after spawning, similar to most of extant coleoids that reproduce only once near the end of their life cycle (LaRosa, 2011). As a consequence, percentages of specimens that survived or remained in the habitats at Nasiłów and Maastricht until the fourth year (approximately) were comparatively small (Figure 22). These specimens might be regarded either as unusually old and/or as stray individuals that could have wandered into the study areas only sporadically.

Schulz (1979, figure 6) illustrated the size distribution of dorsoventral diameter at the protoconch of several early Maastrichtian species of Belemnella from the Kronsmoor and Hemmoor sections (northern Germany). In these sections specimens with a Dp smaller than $10 \mathrm{~mm}$, which would represent individuals younger than c. 2-3 years according to Schmid (1960), were rarely found. In addition, Schulz (1979) observed a relatively wide range of $\mathrm{Dp}$. His records are best interpreted by assuming that the populations at Kronsmoor and Hemmoor consisted of older specimens that lived in slightly deeper waters than did juveniles.

According to Mitchell (2005), the normal habitat for belemnites was the deeper shelf, characterised by shallow-water chalks, clays, sands, and condensed facies. They were rare from reef facies, anoxic shale deposits, and deep-water basin strata. The present results, in combination with those published by Schulz (1979), indicate that belemnites most likely changed their habitat during their life cycle. Small belemnites preferred a shallower-marine habitat, while adults ventured out into open and deeper water, but returned at least during spawning (e.g., Wiese et al., 2009). The 
populations of Bln. gr. kazimiroviensis from the Maastricht and Nasiłów areas are quite similar with a predominance of juvenile individuals and thus maybe considered typical of a relatively nearshore and/or shallower-water environment.

\section{ACKNOWLEDGEMENTS}

We are grateful for support received from M. Machalski (Instytut Paleobiologii PAN, Warsaw) in identifying a cast of Hoploscaphites from Nasiłów and supplying detailed data on the localities of Mełgiew and Lechówka. Sincere thanks are extended to Dr. B. Studencka, curator of palaeozoology at the Museum of the Earth of the Polish Academy of Sciences, Warsaw, for help and loan of the Kongiel's Collection for comparative studies. Thanks go to the reviewers, M. Machalski and M. Kostak for their helpful remarks and critical comments. Two of us (NK and ZR) acknowledge the financial support of the Polish National Science Centre; grant number UMO-2013/09/B/ST10/ 01912.

\section{REFERENCES}

Alekseev, A., Kopaevich, L.F., Ovechkina, M., and Olferiev, A.G. 1999. Maastrichtian and Lower Palaeocene of northern Saratov region (Russian Platform, Volga River): foraminifera and calcareous nannoplankton. Bulletin de l'Institut Royal des Sciences Naturelles de Belgique, Sciences de la Terre, 69-Supplement A:1545.

Arkhangelsky, A.D. 1912. Verkhnemelovyje otlozhenija vostoka evropekskoy Rossii. Materialy dla Geologii Rossii, 25:1-631.

Birkelund, T. 1957. Upper Cretaceous belemnites from Denmark. Det Kongelige Danske Videnskabernes Selskab, Biologiske Skrifter, 9:1-69.

Böhm, J. 1898. Über Ammonites Pedernalis v. Buch. Zeitschrift der deutschen geologischen Gesellschaft, 50:183-201.

Christensen, W.K. 1995. Belemnitella from the Upper Campanian and Lower Maastrichtian Chalk of Norfolk, England. Special Papers in Palaeontology, 51:184.

Christensen, W.K. 1996. A review of the Upper Campanian and Maastrichtian belemnite biostratigraphy of Europe. Cretaceous Research, 17:751-766.

Christensen, W. K. 1997a. The Late Cretaceous belemnite family Belemnitellidae: Taxonomy and evolutionary history. Bulletin of the Geological Society of Denmark, 44:59-88.

Christensen, W.K. 1997b. Palaeobiogeography and migration in the Late Cretaceous belemnite family Belemnitellidae. Acta Palaeontologica Polonica, 42:457-495.
d'Orbigny, A.D. 1840-1842. Paléontologie française; Terrains Crétacés, 1. Céphalopodes. Paris (Masson): 1120 (1840); 121-430 (1841); 431-662 (1842), 148 + 3 pls.

Dubicka, Z. and Peryt, D. 2012. Latest Campanian and Maastrichtian palaeoenvironmental changes: Implications from an epicontinental sea (SE Poland and western Ukraine). Cretaceous Research, 37:272284.

Jagt, J.W.M. 1996. Late Maastrichtian and early Palaeocene index macrofossils in the Maastrichtian type area (SE Netherlands, NE Belgium). Geologie en Mijnbouw, 75:153-162.

Jagt, J.W.M. 2012a. Ammonieten uit het Laat-Krijt en Vroeg-Paleogeen van Limburg. Staringia, 13:154183.

Jagt, J.W.M. 2012b. Belemnitellid coleoids (Mollusca, Cephalopoda) from the type Maastrichtian, the Netherlands and Belgium. Scripta Geologica Special Issue, 8:93-111.

Jagt, J.W.M. 2012c. Belemnieten uit het Laat-Krijt van Limburg. Staringia, 13:128-137.

Jagt, J.W.M., Felder, W.M., Dortangs, R.W., and Severijns, J. 1996. The Cretaceous/Tertiary boundary in the Maastricht type area (SE Netherlands, NE Belgium); a historical account. Geologie en Mijnbouw 75:107-118.

Jagt, J.W.M. and Jagt-Yazykova, E.A. 2012. Stratigraphy of the type Maastrichtian - a synthesis. Scripta Geologica Special Issue, 8:5-32.

Jeletzky, J.A. 1951. Die Stratigraphie und Belemnitenfauna des Obercampan und Maastricht Westfalens, Nordwestdeutschlands und Dänemarks, sowie einige allgemeine Gliederungs-Probleme der jüngeren borealen Oberkreide Eurasiens. Beihefte zum Geologischen Jahrbuch, 1:1-142.

Jeletzky, J.A. 1958. Die jüngere Oberkreide (Oberconiac bis Maastricht) Südwestrußlands und ihr Vergleich mit der Nordwest- und Westeuropas. I. DnjeprDonez-Senke und Nordwestrand des Donezbeckens sowie einige Vergleichs- und Gliederungs-Probleme der russischen borealen Oberkreide. Beihefte zum Geologischen Jahrbuch, 33:1-157.

Jeletzky, J.A. 1965. Taxonomy and phylogeny of fossil Coleoidea (= Dibranchiata). Geological Survey of Canada, Paper 65-2(42):72-76.

Keutgen, N. 1997. Belemnella (Belemnella) cf. praearkhangelskii Naidin, 1964 from the Vijlen Member at Altembroeck (NE Belgium, Early Maastrichtian). Geologie en Mijnbouw, 75:341-347.

Keutgen, N., Remin, Z., and Walaszczyk, I. 2012. Early representatives of the belemnite genus Belemnella (Cephalopoda) from the uppermost CampanianLower Maastrichtian of the Middle Vistula River section, central Poland. Acta Geologica Polonica, 62:535-559.

Kongiel, R. 1962. On belemnites from the Maastrichtian, Campanian, and Santonian sediments in the Middle 
Vistula Valley (Central Poland). Prace Muzeum Ziemi, 5:1-148.

Łopuski, C. 1911. Przyczynki do znajomości fauny kredowej guberni Lubelskiej. Sprawozdania Towarzystwa Naukowego Warszawskiego, 4:104140.

LaRosa, G.A. 2011. Learning from the soft intelligence: cephalopods as indicators of ocean changes. ENSP386 Internship Paper, 1-26. UMD Library, University of Maryland. http://drum.lib.umd.edu/bitstream/handle/1903/12427/

LaRosa_ResearchPaper.pdf;jses-

sionid=9FF9183B07277BD5A874E3854-

FAD495E? sequence $=11$ (accessed 22 November 2015).

Machalski, M. 1996. Scaphitid ammonite correlation of the Late Maastrichtian deposits in Poland and Denmark. Acta Palaeontologica Polonica, 41:369-383.

Machalski, M. 1998. Granica kreda-trzeciorzęd w przełomie Wisły. Przegląd Geologiczny, 46:11531161.

Machalski, M. 2005a. The youngest Maastrichtian ammonite faunas from Poland and their dating by scaphitids. Cretaceous Research, 26:813-836.

Machalski, M. 2005b. Late Maastrichtian and earliest Danian scaphitid ammonites from central Europe: Taxonomy, evolution, and extinction. Acta Palaeontologica Polonica, 50:653-696.

Machalski, M., Vellekoop, J., Dubicka, Z., Peryt, D., and Harasimiuk, M. 2016. Late Maastrichtian cephalopods, dinoflagellate cysts and foraminifera from the Cretaceous-Paleogene succession at Lechówka, southeast Poland: Stratigraphic and environmental implications. Cretaceous Research, 57:208-227.

Machalski, M. and Walaszczyk, I. 1987. Faunal condensation and mixing in the uppermost Maastrichtian/ Danian Greensand (Middle Vistula Valley, central Poland). Acta Geologica Polonica, 37:75-91.

Mitchell, S.F. 2005. Eight belemnite biohorizons in the Cenomanian of northwest Europe and their importance. Geological Journal, 40:363-382.

Naidin, D.P. 1952. Verkhnemelovye belemnity zapadnoj Ukrainy. Trudy Moskovskogo Geologo-Razvedochnogo Instituta imemi S. Ordzhinikidze, 27:1-126.

Naidin, D.P. 1964. Verkhnemelovye belemnitelly i belemnelly Russkoj platformy i nekotorykh sopredel'nykh oblastej. Byulleten' Moskovskogo Obshchestva Ispytatelej Prirody, Otdel Geologicheskii, 39:85-97.

Naidin, D.P. 1975. Pozdnemaastrikhskie belemnitellidy Evrazii. p. 91-108. In Menner, V.V., Moskvin, M.M., Naidin, D.P., Solovyev, A.N., and Shimansky, V.N. (eds.), Razvitie i smena organicheskogo mira na rubezhe mezozoja i kajnozoja. Nauka, Moskva.

Naidin, D.P. and Beniamovski, V.N. 2006. The Campanian-Maastrichtian stage boundary in the Aktulagai Section (North Caspian Depression). Stratigraphy and Geological Correlation, 14:433-443.
Nowak, J. 1913. Untersuchungen über die Cephalopoden der oberen Kreide in Polen. III Teil. Bulletin International de l'Académie des Sciences de Cracovie. Classe des Sciences Mathématiques et naturelles, Série B, Sciences Naturelles, 335-415.

Pavlow, A.P. 1914. Jurassic and Lower Cretaceous Cephalopoda of North Siberia. Zapisky Imperatorskoj Akademii Nauk Po Fiziko- Matematitcheskomu Otdeleniu, 21:1-68.

Pożaryski, W. 1938. Senons Stratigraphie im Durchbruch der Weichel zwischen Rachów und Puławy in Mittelpolen (in Polish with German summary). Biuletyn Państwowego Instytutu Geologicznego, 6:1-94.

Racki, G., Machalski, M., Koeberl, C., and Harasimiuk, M. 2011. The weathering-modified iridium record of a new Cretaceous-Palaeogene site at Lechówka near Chełm, SE Poland, and its palaeobiologic implications. Acta Palaeontologica Polonica, 56:205-215.

Rasmussen, A., Rasmussen, L., and Hansen, T. 2011. Fossiler fra Stevns Klint, Møn og Nordjylland. Store Heddinge (Østsjællands Museum), 1-89.

Remin, Z. 2008. Artificial Kohonen neural networks as a tool in paleontological taxonomy - an introduction and application to Late Cretaceous belemnites (in Polish with English summary). Przegląd Geologiczny, 56:58-66.

Remin, Z. 2012. The Belemnella stratigraphy of the Campanian-Maastrichtian boundary: a new methodological and taxonomic approach. Acta Geologica Polonica, 62:495-533.

Remin, Z. 2015. The Belemnitella stratigraphy of the Upper Campanian-basal Maastrichtian of the Middle Vistula section, central Poland. Geological Quarterly, 59:783-813.

Remin, Z., Cyglicki, M., Gościmski, B., Barski, M., Dubicka, Z., and Roszkowska-Remin, J. 2015. Reassessment of the K/T boundary site at Nasiłów, Poland new sedimentological model in relation to Chicxulub impact, p. 438. In Abstract Book of the 31st IAS Meeting of Sedimentology, 22nd-25th June 2015. Kraków, Poland.

Rousseau, L. 1842. Description des principaux fossils de la Crimée, 2, p. 781-823. In Demidoff, M.A. de (ed.), Voyage dans la Russie Méridionale et la Crimée par la Hongrie, la Valachie et la Moldavie, etc., E. Bourdin, Paris.

Schmid, F. 1960. Zur Ontogenie einiger Vertreter der Gattung Belemnitella D'Orbigny and Belemnella Nowak. Geologisches Jahrbuch, 77:533-540.

Schulz, M.-G. 1979. Morphometrisch-variationsstatistische Untersuchungen zur Phylogenie der Belemniten-Gattung Belemnella im Untermaastricht NWEuropas. Geologisches Jahrbuch, A47:3-157.

Skołozdrówna, Z. 1932. Znaczenie alveoli i szczeliny alveolarnej dla systematyki rodzaju Belemnitella. Posiedzenia Naukowe, Państwowego Instytutu Geologicznego, 32:117.

Świerczewska-Gładysz, E. 2006. Late Cretaceous siliceous sponges from the Middle Vistula River Valley 
(Central Poland) and their palaeoecological significance. Annales Societatis Geologorum Poloniae, 76:227-296.

Świerczewska-Gładysz, E. and Olszewska-Nejbert, D. 2006. The origin of phosphatized sponges from the Danian glauconitic sandstone from Nasiłów (central Poland, Vistula River valley). Przegląd Geologiczny, 54:710-719.

von Zittel, K.A. 1895. Grundzüge der Palaeontologie (Palaeozoologie). R. Oldenburg, München/Leipzig.

Walaszczyk, I., Dubicka, Z., Olszewska-Nejbert, D., and Remin, Z. 2016. Integrated biostratigraphy of the Santonian through Maastrichtian (Upper Cretaceous) of extra-Carpathian Poland. Acta Geologica Polonica, 66:313-350.

Ward, P.D. and Kennedy, W.J. 1993. Maastrichtian ammonites from the Biscay region (France, Spain). Paleontological Society Memoir, 34:1-56.
Wiese, F., Košták, M., and Wood, C.J. 2009. The Upper Cretaceous belemnite Praeactinocamax plenus (Blainville, 1827) from Lower Saxony (Upper Cenomanian, northwest Germany) and its distribution pattern in Europe. Paläontologische Zeitschrift, 83:309-321.

Żarski, M., Jakubowski, G., and Gawor-Biedowa, E. 1998. The first Polish find of a Lower Paleocene crocodile Thoracosaurus Leidy, 1852; geological and palaeontological description. Geological Quarterly, 42:141-160.

Zijlstra, J.P.P., Brouwers, M.H.M.P., Brinkhuis, H., and de Boer, P.L. 1996. Microfacies analysis of Cretaceous/ Tertiary boundary sections in the quarries Geulhemmerberg and Curfs, SE Netherlands. Geologie en Mijnbouw, 75:133-151. 